\title{
National Emission Standards for Hazardous Air Pollutants Submittal - 1996
}

\author{
June 1997
}

Work Performed Uheer Contract $N$

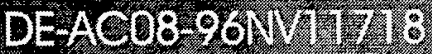

Piesoriec by

bententwheres

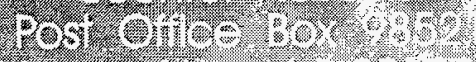

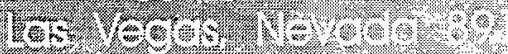

\section{8}


This report has been reproduced directly from the best available copy.

Available to DOE and DOE contractors from the:

Office of Scientific and Technical Information

P.O. Box 62

Oak Ridge, Tennessee 37831

Prices available from (423) 576-8401

Available to public from the:

National Technical Information Service

U.S. Department of Commerce

5285 Port Royal Rd.

Springfield, VA 22161

Prices available from (703) $487-4650$

\section{DISCLAIMER}

This report was prepared as an account of work sponsored by an agency of the United States Government. Neither the United States Government nor any agency thereof, nor any of their emplcyees, makes any warranty, express or implied, or assumes any legal liability or responsibility for the accuracy, completeness, or usefulness of any information, apparatus, product, or process disclosed, or represents that its use would not infringe privately owned rights. Reference herein to any specific commercial product, process, or service by trade name, trademark, manufacturer, or otherwise does not necessarily constitute or imply its endorsement, recommendation, or favoring by the United States Government or any agency thereof. The views and opinions of authors expressed herein do not necessarily state or reflect those of the United States Government or any agency thereof. 


\section{National Emission Standards for Hazardous Air Pollutants Submittal - 1996}

Author

Stuart C. Black

Editor

Yvonne E. Townsend

June 1997

Work Performed Under Contract No.

DE-AC08-96NV11718

Prepared by:

Bechtel Nevada

Post Office Box 98521

Las Vegas, Nevada 89193-8521

DUSTRIBUTON OF AMIS DOCUMENT IS UNLIMITE 


\section{TABLE OF CONTENTS}

Page

List of Figures $\ldots \ldots \ldots \ldots \ldots \ldots \ldots \ldots \ldots \ldots \ldots \ldots \ldots \ldots \ldots \ldots \ldots \ldots$ iv

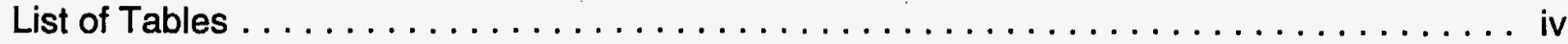

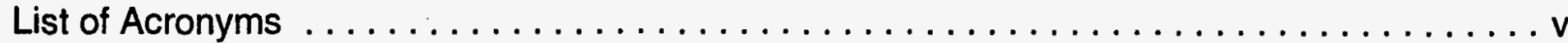

Operations Office and Site Information $\ldots \ldots \ldots \ldots \ldots \ldots \ldots \ldots \ldots \ldots \ldots \ldots$

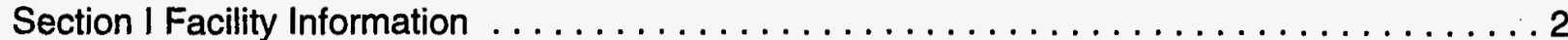

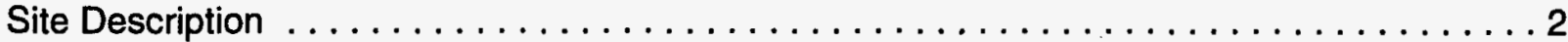

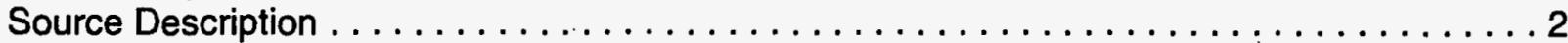

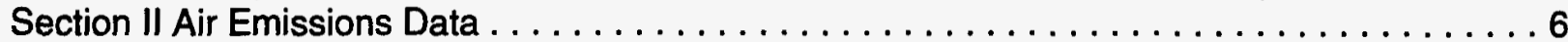

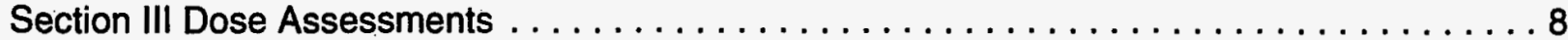

Summary of Input Parameters $\ldots \ldots \ldots \ldots \ldots \ldots \ldots \ldots \ldots \ldots \ldots \ldots \ldots \ldots$

Compliance Assessment $\ldots \ldots \ldots \ldots \ldots \ldots \ldots \ldots \ldots \ldots \ldots \ldots \ldots \ldots \ldots \ldots$

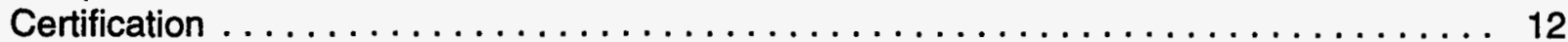

Section IV Additional Information $\ldots \ldots \ldots \ldots \ldots \ldots \ldots \ldots \ldots \ldots \ldots \ldots \ldots \ldots \ldots$

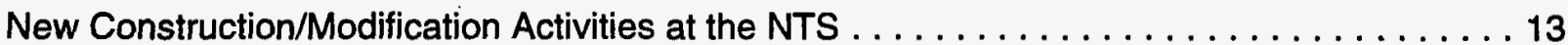

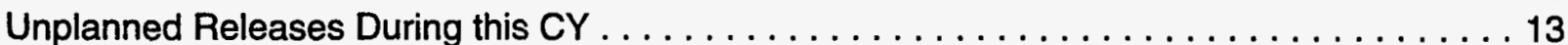

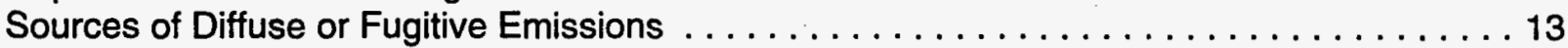

\section{LIST OF APPENDICES}

Appendix A Public Dose Calculation for the Atlas Tritium Incident . . . . . . . . . . . A-1

Appendix B Emissions from Containment Ponds . . . . . . . . . . . . . . . . . . B -1

Appendix $C$ Radionuclide Inventory of Radioanalytical Laboratories . . . . . . . . . C-1

Appendix D Diffuse Source Atmospheric Tritium Emissions .................. D-1

Appendix E Resuspended Plutonium from Yucca Flat and Other Areas . . . . . . . . . . . E-1

Appendix $F$ Identification and Justification for the Development of Meteorological

Data used as input to CAP88-PC . . . . . . . . . . . . . . . . . . F F-1

Appendix G Supplemental Information $\quad$ G-1

Appendix $\mathrm{H}$ Distribution List $\ldots \ldots \ldots \ldots \ldots \ldots \ldots \ldots \ldots \ldots \ldots \ldots \ldots \ldots \ldots \ldots$ 


\section{LIST OF FIGURES}

Page

Figure 1.0 Map of the Area Around the NTS $\ldots \ldots \ldots \ldots \ldots \ldots \ldots \ldots \ldots \ldots$

Figure 2.0 Nuclear Testing Areas on the NTS $\ldots \ldots \ldots \ldots \ldots \ldots \ldots \ldots \ldots \ldots \ldots$

Figure 3.0 Photograph of a Tunnel Portal $\ldots \ldots \ldots \ldots \ldots \ldots \ldots \ldots \ldots \ldots \ldots \ldots \ldots$

Figure 4.0 Photograph of Tunnel Containment Ponds $\ldots \ldots \ldots \ldots \ldots \ldots \ldots \ldots \ldots$

Figure 5.0 Photograph of the Building 650 Hood Ventilation Stacks Seen

from Above ................................... 19

Figure 6.0 Location of Nuclear Device Safety Test $\ldots \ldots \ldots \ldots \ldots \ldots \ldots \ldots \ldots \ldots$

Figure F.1 Location of MEDA Stations on the NTS . . . . . . . . . . . . . . F-3

\section{LIST OF TABLES}

Table 1.0 Summary of Estimated Inventory of ${ }^{239+240} \mathrm{Pu}$ in Surface Soil $(0$ to $5 \mathrm{~cm})$

at Studied Sites .............................. 5

Table 2.0 Summary of Annual Air Emissions Data by Source (Multiply Ci by 37

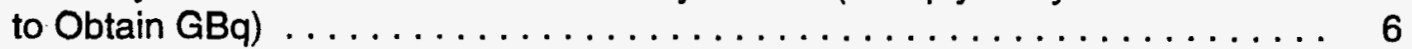

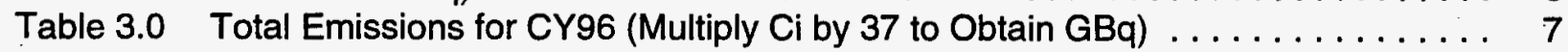

Table 4.0 Summary of CY96 CAP88-PC Calculations of EDE to the Maximally Exposed Offsite Individual - Springdale, Nevada ${ }^{(a)} \ldots \ldots \ldots \ldots \ldots$

Table 5.0 Effective Dose Equivalent Tabulation by Location (Multiply mrem by $10^{-2}$ for

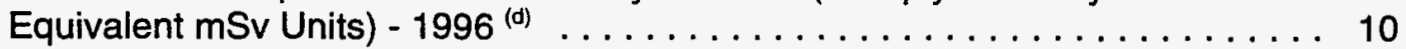

Table A.1 HTO in Air Results for the North Sampler, Atlas Facility - 1996 . . . . . . . . . . A-2

Table B.1 Tritium Water Effluents in $1996 \ldots \ldots \ldots \ldots \ldots \ldots \ldots \ldots \ldots \ldots \ldots$. . . . . . . . . .

Table C.1 Building 650 Health Physics Laboratory Inventory Compared to NESHAP . . . . C-2

Table D.1 Airborne Tritium Sampling Results During CY96 . . . . . . . . . . . . . . . . . D-2

Table E.1 Airborne ${ }^{239+240}$ Pu Detected by Area 3 Air Samplers . . . . . . . . . . . . . . . . E-1

Table E.2 Offsite EDE Calculated from Resuspension of Pu from

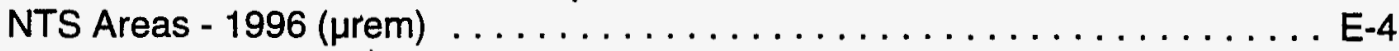




\section{LIST OF ACRONYMS}

ARLSORD Air Resources Laboratory,Special Operations and Research Division

BN Bechtel Nevada

CY96 Calendar Year 1996

DOE/NV U.S. Department of Energy, Nevada Operations Office

DRA Desert Rock Meteorological Observatory

DRI Desert Research Institute

EDE Effective Dose Equivalent

EPA U.S. Environmental Protection Agency

GCD Greater Confinement Disposal

HSC Hazardous Materials Spill Center

HTO Tritiated Water

LANL Los Alamos National Laboratory

LLW Low-Level Waste

MDC Minimum Detectable Concentration

MEDA Meteorological Data Acquisition System

MEI Maximally Exposed Individual

MIDNET Meteorological Data Network

NESHAP National Emission Standard for Hazardous Air Pollutants

NLVF North Las Vegas Facility

NOAA National Oceanic and Atmospheric Administration

NTS Nevada Test Site

R\&IE-LV Radiation \& Indoor Environments National Laboratory - Las Vegas

RWMS Radioactive Waste Management Site

RWMS-3 Area 3 Radioactive Waste Management Site

RWMS-5 Area 5 Radioactive Waste Management Site

STAR

TRU

Stability Array

UCC

Transuranic

Yucca Flat Meteorological Observatory 


\section{U.S. Department of Energy Air Emissions Annual Report (under Subpart H, Title 40 C.F.R. 61.94) \\ Calendar Year (CY) 1996}

Site Name: Nevada Test Site

\section{Operations Office Information}

Office: DOE Nevada Operations Office

Address: $\quad$ P. O. Box 98518

Las Vegas. NV 89193-8518

Contact: Kenneth A. Hoar. Director

Phone: (702) 295-1146

Environmental Protection Division

\section{Site Information}

Operator: Bechtel Nevada

Address: $\quad$ P. O. Box 98521

Las Vegas, NV 89193-8521

Contact: James R. Kannard

Phone: (702) 295-5689

Assistant General Manager, Environmental Management 


\section{SECTION I \\ FACILITY INFORMATION}

\section{SITE DESCRIPTION}

The Nevada Test Site (NTS) is operated by the U.S. Department of Energy, Nevada Operations Office (DOE/NV) as the site for nuclear weapons testing. It is located in Nye County, Nevada, with the southeast corner of the NTS about $90 \mathrm{~km}(56 \mathrm{mi})$ northwest of Las Vegas, Nevada. The NTS covers about $3500 \mathrm{~km}^{2}\left(1350 \mathrm{mi}^{2}\right)$, an area larger than Rhode Island. Its size is about 46 to $56 \mathrm{~km}$ ( 28 to $35 \mathrm{mi}$ ) east to west and from 64 to $88 \mathrm{~km}$ ( 40 to $55 \mathrm{mi}$ ) north to south. The NTS is surrounded, except on the south side, by public exclusion areas (Nellis Air Force Range Complex) that provide another 24 to $104 \mathrm{~km}$ (15 to $65 \mathrm{mi}$ ) between the NTS and public lands (Figure 1.0). The NTS is characterized by desert valley and Great Basin mountain topography, with a climate, flora, and fauna typical of the southwest deserts. Population density within 150 $\mathrm{km}$ (93 $\mathrm{mi}$ ) of the NTS is only about 0.5 persons per square $\mathrm{km}$, excluding the Las Vegas area. Restricted access, low population density in the surrounding area, and extended wind transport times are advantageous factors for the activities conducted at the NTS. Surface waters are scarce on the NTS and there is great depth to slow-moving groundwater.

\section{SOURCE DESCRIPTION}

The source of radionuclides includes current and previous activities conducted on the NTS. Figure 2.0 is a map of the NTS which shows the areas used for such activities. The NTS was the primary location for testing of nuclear explosives in the Continental U.S. between 1951 and 1992. Historical testing has included (1) atmospheric testing in the 1950s and early 1960s,

(2) earth-cratering experiments, and (3) open-air nuclear reactor and rocket engine testing. Since the mid 1960s, testing of nuclear devices has occurred underground in drilled vertical holes or in mined tunnels. By order of the President, no nuclear tests have been conducted since September 1992. Limited non-nuclear testing includes spills of hazardous materials at the Hazardous Materials Spill Center (HSC). Processing of radioactive materials is limited to laboratory analyses, and handling is restricted to transport, storage, and assembly of nuclear explosive devices and operation of radioactive waste management sites (RWMSs) for low-level radioactive, transuranic, and mixed waste. Monitoring and evaluation of the various activities conducted onsite indicate that the potential sources of offsite radiation exposure in 1996 were releases from the following: (1) evaporation of tritiated water (HTO) from containment ponds that receive drainage water from $E$ tunnel in Area 12 and from wells used for site characterization studies, (2) onsite radioanalytical laboratories, (3) the Area 5 RWMS facility, and (4) diffuse sources of tritium and resuspension of plutonium. The following sections present a general description of the sources on the NTS.

At the North Las Vegas Facility (NLVF), operated for DOE/NV by Bechtel Nevada (BN), there was an unusual occurrence in 1995 that led to a very small potential exposure to an offsite person. The incident involved the release of HTO, and a description of the incident and the method of calculating the effective dose equivalent (EDE) for offsite exposure are set forth in Appendix A. A still smaller emission from this source continued into 1996.

\section{Ground Seepage of Noble Gases}

Ground seepage may be enhanced when changes in ambient pressure act like a pump to bring small amounts of noble gases up through the overburden and into the atmosphere from the cavity created by a nuclear test. This process, sometimes referred to as "atmospheric pumping," creates a diffuse source of radiological effluents. These area sources are rare and therefore not routinely monitored. The phenomenon is usually restricted to events conducted in the Pahute Mesa region of the NTS. These seepages are from nuclear tests conducted prior to 1993. 
Krypton-85 is generally detected on the NTS at air concentrations consistent with data previously collected at offsite areas by the U.S. Environmental Protection Agency's (EPA's) Radiation and Indoor Environments National Laboratory - Las Vegas (R\&IE-LV). During 1996, krypton-85 was detected at all environmental monitoring stations at an average level of $25.2 \mathrm{pCi} / \mathrm{m}^{3}$, consistent with previous years. This year, there were no differences between the sampling locations on Pahute Mesa and in Yucca Flat. Therefore, a source term for this emission is not calculated.

\section{Tunnel Operations}

Nuclear tests have been conducted within tunnel complexes mined into the Rainier Mesa region. No such tests were conducted in 1996. When tests were conducted, purging gases from the tunnel occasionally resulted in releases of radioactivity, and contaminated water drained from them (see below). Figure 3.0 is a photograph of a tunnel portal.

\section{Containment Ponds}

Water contaminated with radionuclides seeped from the tunnels in Area 12 and was collected in containment ponds where some evaporated and some seeped into the soil. A photograph of tunnel containment ponds is provided as Figure 4.0. The tunnels have been sealed, but water continues to seep only from $E$ Tunnel. The only radiological contaminant which produces a measurable air emission from evaporation of the water is ${ }^{3} \mathrm{H}$ (as HTO). It is expected to cease completely in the near future, as remedial actions are being implemented. Calculation of the source term for this emission is described in Appendix $B$.

To characterize the groundwater regime under the NTS, suitable wells are being drilled in the vicinity of certain underground tests and at other locations. During these drilling operations, contaminated water can be pumped from the wells. This water is diverted to lined containiment ponds if the tritium level exceeds $2 \times 10^{5} \mathrm{pCi} / \mathrm{L}$, as required by the state. The emission was smaller this year. Calculations for this activity are also described in Appendix $B$.

\section{Drillbacks}

Following underground nuclear tests, slant wells are drilled so core samples can be taken from the cavity formed by the nuclear detonation for analysis and diagnosis. This is referred to as core sampling and is accomplished by drilling into the area of interest and recovering samples using special drilling equipment. Radioactive material may be discharged into the atmosphere during these operations. No drillback activities occurred during 1996.

\section{Laboratories}

Radiological analyses are conducted by $B N$ in a laboratory located in Building 650 , and by Los Alamos National Laboratory (LANL) in Building 701, both in Mercury. Because these facilities primarily process environmental samples, very little radioactivity passes through them. However, there is potential for some radionuclides to be discharged into the atmosphere through the hood ventilation system during sample processing, particularly of spiked samples, or from loss of radioactive standards. Figure 5.0 is a photograph of the Building 650 hood ventilation stacks seen from above. The source term for Building 701 was limited to $500 \mu \mathrm{Ci}$ of tritium. The source term for Building 650 is described in Appendix B. In general, evaporation and spills from samples containing HTO, radioiodines, or noble gases are conservatively estimated by assuming all such materials are released. Radioactive standards contained most of the activity potentially releasable. Non-volatile materials are controlled by keeping their inventory below the possession limits set forth in Appendix E to Title 40 C.F.R. 61 as shown in Appendix C. 


\section{Radioactive Waste Management Sites (RWMSs)}

The RWMSs in Areas 3 and 5 (RWMS-3 and -5) are used for the disposal of low-level radioactive waste (LLW). The RWMS-5 is used for accumulation of mixed waste, storage of transuranic (TRU) and mixed TRU wastes, and contains the Greater Confinement Disposal (GCD) Test Unit and 12 GCD boreholes (only a few have any waste). Disposal is accomplished by the use of pits and trenches. Concrete pads are used for temporary storage of certain wastes. At RWMS-5, only packaged wastes are accepted for disposal. The facility is considered a diffuse source of radiological effluents. The only radioactive effluent detected by the various types of samplers surrounding the site is HTO in atmospheric moisture. The calculation of the HTO source term is explained in Appendix D. The RWMS-3 LLW site is in a location where surface soil has been contaminated by deposited plutonium (see below), and resuspension of this soil by wind or vehicular activity results in above background levels of plutonium being detected in air samples collected nearby.

\section{Plutonium Contaminated Surface Areas}

Surface soils in certain areas on and off the NTS were contaminated with plutonium from either nuclear device safety, atmospheric, or cratering tests (the Plowshare Program) using nuclear explosives. Investigations of these areas during the Nevada Applied Ecology Group studies ${ }^{(1)}$ as expanded by the Desert Research Institute $(\mathrm{DRI})^{(2)}$ developed the inventories of plutonium shown in Table 1.0. These areas could become sources of plutonium exposure if the contaminated soils were to be resuspended; e.g., during surface cleanup, construction, vehicular travel, or similar activities. Figure 6.0 is a map showing the approximate locations of the nuclear device safety tests on the NTS. There are air samplers at or near almost all of these onsite areas. Plutonium analyses of the glass-fiber filters from these samplers indicate that the majority of the results are less than the minimum detectable concentration (MDC) and most of those are even less than the two standard deviation (2s) counting error. The results that are higher than the MDC are from air samplers in areas where operational activities can cause contaminated surface soil to become resuspended. These areas are considered diffuse sources of radioactive effluents, although plutonium is the only detectable one. The calculation of the source term for these plutonium contaminated areas is explained in Appendix $E$.

(1) Friesen, H.N., 1992, "Summary of the Nevada Applied Ecology Group and Correlative Programs Report" DOE/NV-357, Nevada Operations Office, U.S. Department of Energy, Las Vegas, Nevada.

(2) McArthur, R.D., 1991, "Radionuclides in Surface Soil at the Nevada Test Site Report" DOE/NV/1048502, Nevada Operations Office, U.S. Department of Energy, Las Vegas, Nevada. 
Table 1.0 Summary of Estimated Inventory of ${ }^{239+240} \mathrm{Pu}$ in Surface Soil $(0$ to $5 \mathrm{~cm})$ at Studied Sites

\begin{tabular}{|c|c|c|c|c|c|}
\hline SITE (ON NTS) & AREA $\left(\mathrm{km}^{2}\right)$ & $\begin{array}{l}\text { NUMBER } \\
\text { SAMPLES }\end{array}$ & $\begin{array}{c}\text { EST. INVENTORY } \\
\text { (CURIES) } \\
\end{array}$ & $\begin{array}{c}95 \% \\
\text { CONF. INTERVAL } \\
\text { (CURIES) } \\
\end{array}$ & $\begin{array}{l}{ }^{239+240} \mathrm{Pu} \text { AIR CONC. } \\
\text { ANNUAL AVG. }(X \pm 2 s) \\
\text { IN } 10^{-18} \mu \mathrm{Ci} / \mathrm{mL} \text { UNITS }\end{array}$ \\
\hline PROJECT 56 (AREA 11) & 4.83 & 205 & 36 & $28-44$ & $23 \pm 39$ \\
\hline GMX (AREA 5) $)^{(a)}$ & 0.125 & 111 & 1.5 & $1.1-1.9$ & $5 \pm 5$ \\
\hline $\begin{array}{l}\text { LITTLE FELLER II } \\
\text { (Area 18) }\end{array}$ & 0.375 & 712 & $32^{(c)}$ & $22-41$ & \\
\hline PALANQUIN (AREA 20) ${ }^{(b)}$ & 3.895 & 148 & $13^{(c)}$ & $6-21$ & $1.6 \pm 1.2$ \\
\hline SEDAN (AREA 10) & 28.264 & & 111.2 & & $12 \pm 13$ \\
\hline T2 SERIES (AREA 2) ${ }^{(d)}$ & 30.100 & & 26.7 & & $8 \pm 16$ \\
\hline $\begin{array}{l}\text { VARIOUS TESTS } \\
\text { (AREA 9) }\end{array}$ & & & 89 & & $245 \pm 216$ \\
\hline AREA $13^{(a)}$ & 4.02 & 169 & 46 & $28-64$ & \\
\hline $\begin{array}{l}\text { CLEAN SLATE \& DOUBLE } \\
\text { TRACKS } \\
\end{array}$ & 2.6 & 236 & 61.8 & & \\
\hline
\end{tabular}

(a) Safety tests of nuclear devices.

(b) Plowshare tests (PALANQUIN and CABRIOLET sites in Area 20 combined).

(c) Inventory consists of ${ }^{239+240} \mathrm{Pu}+{ }^{241} \mathrm{Am}$

(Gilbert, NVO-181 p. 425; NVO-272, pp. 381-429; McArthur, DOE/NV10162-20).

(d) Weapons effects tests. 


\section{SECTION II \\ AIR EMISSIONS DATA}

Each potential source of NTS emissions was characterized by one of the following methods:

(1) monitoring methods and procedures previously developed at the NTS; (2) a yearly radionuclide inventory of the source, assuming that volatile radionuclides are released to the environment; (3) the measurement of tritiated water (as $\mathrm{HTO}$ or $\mathrm{T}_{2} \mathrm{O}$ ) concentration in liquid effluents discharged to containment ponds and assuming all the effluent evaporates over the course of the year to become an air emission; or (4) using a combination of environmental measurements and CAP88-PC to calculate emissions (generally confirmed by offsite air measurements). Appendices $A$ through $E$ describe the methods used to determine the emissions from the sources listed in Section I. In accordance with Title 40 C.F.R. 61.93.(b).(4), no credit was taken for pollution control equipment in determining air emissions.

The emissions for National Emission Standards for Hazardous Air Pollutants (NESHAP) reporting are listed in Table 2.0. They are very conservative (worst-case) and are used in Section III to calculate the EDE to the maximally exposed individual offsite (MEI). Offsite environmental surveillance data, where available, are used to confirm that calculated emissions are, indeed, conservative.

Table 2.0 Summary of Annual Air Emissions Data by Source (Multiply Ci by 37 to Obtain GBq)

Point

Source

Building 701

Building A-1

(Atlas)

Grouped

Sources

Building 650
Laboratory (12)

None

Control

None

None

None

Containment ${ }^{(\mathrm{b})}$

Pond: Area 12

Area 20

None

$0 \%$

$24 \mathrm{~km}$

Efficiency

Distance to

Nearest Receptor

Nuclide

${ }^{3} \mathrm{H}$

${ }^{3} \mathrm{H}$

$0.1 \mathrm{~km}$

$0 \%$

$24 \mathrm{~km}$

$\mathrm{H}$

Quantity (Ci)

$5.0 \times 10^{-4}$

$5.2 \times 10^{-2}$

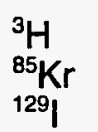

$2.0 \times 10^{-4}$

$1.9 \times 10^{-2}$

$1.5 \times 10^{-6}$

${ }^{3} \mathrm{H}$

${ }^{3} \mathrm{H}$

Non-Point

Sources

Yucca Flat: ${ }^{(c)}$

Area 3

Area 9

RWMS-5 ${ }^{\text {(c) }}$

Other $\operatorname{Areas}^{(d)}$

None

None

None

None
$0 \%$

$\begin{array}{ll}0 \% & 54 \mathrm{~km} \\ 0 \% & 53 \mathrm{~km} \\ 0 \% & 42 \mathrm{~km} \\ 0 \% & 42 \mathrm{~km}\end{array}$

$56 \mathrm{~km}$ $42 \mathrm{~km}$

(a) $x$ is number of vents or stacks.

(b) Evaporation of all tritiated water effluents is assumed.

(c) Emissions based on environmental surveillance data.

(d) Described in Appendix E. 
A summary of the NTS total calendar year 1996 (CY96) emissions for NESHAP's reporting, by radionuclide, is provided in Table 3.0 .

Table 3.0 Total Emissions for CY96 (Multiply Ci by 37 to Obtain GBq)

$\begin{array}{lrc}\text { Radionuclide } & \text { Half-Life (days) } & \text { Annual Quantity (Ci) } \\ {^{3} \mathrm{H}} } & 4510 & 271 \\ { }^{129} \mathrm{I} & 5.7 \times 10^{9} & 1.5 \times 10^{-6} \\ { }^{239+240} \mathrm{Pu} & 8.8 \times 10^{6} & 3.9 \times 10^{-1}\end{array}$

Note: This table includes all worst-case point and diffuse source releases. 


\section{SECTION III \\ DOSE ASSESSMENTS}

\section{SUMMARY OF INPUT PARAMETERS}

CAP88-PC was used to calculate EDEs to offsite residents. The input parameters were the radionuclide releases listed in Section II above as determined from effluent monitoring performed by the contractor, from evaporation of HTO, and from calculations of diffuse source emissions that are based on environmental monitoring data. The latter includes measurable particulate emissions of ${ }^{239+240} \mathrm{Pu}$ originating in certain areas of the NTS and Nellis Air Force Range Complex, and HTO detected at the boundary of the RWMS.

To calculate the amount of HTO evaporated, measurements of HTO concentration in the containment ponds for the first and fourth quarters of 1995 were compared. These concentrations were equal; i.e., within the measurement error, and the surface areas were approximately equal and thus the volume, so all the HTO influent to the ponds was assumed to have evaporated. This was a conservative estimate, as no allowance for infiltration into the soil column was made. This is assumed to be true for 1996 also. A description of the source term estimated for this emission source is contained in the Appendices.

The source data listed above are used with five stability array (STAR) data files as input to CAP88-PC. The five STARs for the NTS include the files with names NTSYUCCA, AREA05, MEDA20, DESERTRK, and T-TUNNEL. NTSYUCCA is used for sources on Yucca Flat (Areas 1, $2,3,4,6,7$, and 9); AREA05 is used for sources on Frenchman Flat; DESERTRK is used for sources in Mercury; MEDA20 is used for sources in Areas 19 and 20; and T-TUNNEL is used for the tunnel pond sources in Area 12. MEDA20, T-TUNNEL, and AREA05 were developed by the Air Resources Laboratory, Special Operations and Research Division (ARL/SORD) using data obtained from the meteorological stations located near the boundary of Areas 19 and 20 on Pahute Mesa, near the tunnels in Area 12, and at Well 5B in Area 5. The other two files were provided by the National Climatic Data Center in North Carolina based on data from meteorological stations in Yucca Flat and at the Desert Rock airstrip. The ARL/SORD assessment is attached as Appendix $G$. For each of these five STARs there may be a different location for the MEl; but when the contributions of all the NTS sources to a given location are considered, only one location would receive the maximum exposure. In this case, the location was Springdale, Nevada, with a population of 20 persons. See Figure 1.0 for residences and communities around the NTS.

The EDE, in mrem, to the MEI (a resident in Springdale, Nevada) was calculated using CAP88-PC for each of the listed sources in Section II. A summary of sources contributing to the EDE is shown in Table 4.0. Calculation of this EDE requires summing the contribution from all sources, as shown in Table 5.0. The sources listed as containment ponds in Area 12 and Laboratory Buildings 650 and 701 (Mercury) were added to the NESHAP program in 1991 for 1990 emissions. Consideration of diffuse sources, such as soils contaminated by safety and other nuclear device tests (as detected by air sampling) were added in the 1992 report to complete the possible sources of emission of radioactivity on the NTS. Recently, a resuspension calculation has been used for source terms from contaminated areas. Appendices A through $E$ contain estimates of radionuclides, which have or could have been released in 1996.

Descriptions and estimations of the errors involved in each step of the process (measurement, monitoring, and calculation); estimations of potential releases; and worst-case scenarios are also included where possible. Evaporative and resuspension emissions are also compared to EPA suggested methods as a check on the relative values produced. 


\section{COMPLIANCE ASSESSMENT}

Table 4.0 Summary of CY96 CAP88-PC Calculations of EDE to the Maximally Exposed Offsite Individual - Springdale, Nevada ${ }^{(a)}$

Source

Tunnel Pond (Area 12)

Laboratories (Area 23)

Yucca Flat (Area 3)

(Area 9)

RWMS (Area 5)

Area 20

Other Areas ${ }^{(d)}$

TOTAL EDE
Distance to Individual and Direction

56 km WSW

$78 \mathrm{~km}$ WNW

$62 \mathrm{~km} \mathrm{~W}$

$64 \mathrm{~km} \mathrm{~W}$

$74 \mathrm{~km}$ WNW

$42 \mathrm{~km} \mathrm{SW}$

$\cdots$

\section{Effective Dose Equivalent} (mrem) $^{(b)}$

$2.5 \times 10^{-5(\mathrm{c})}$

$1.9 \times 10^{-8}$

$5.0 \times 10^{-3}$

$9.5 \times 10^{-3}$

$4.3 \times 10^{-6}$

$4.6 \times 10^{-4}$

$\underline{9.2 \times 10^{-2}}$

(a) Location of residences and communities around the NTS is shown in Figure 1.0.

(b) For mSv, multiply by $10^{-2}$.

(c) Assumes evaporation of all HTO influents to ponds.

(d) Described in Appendix E. 
Table 5.0 Effective Dose Equivalent Tabulation by Location (Multiply mrem by $10^{-2}$ for Equivalent mSv Units) $-1996^{(\text {(d) }}$

\begin{tabular}{|c|c|c|c|c|c|c|c|c|}
\hline \multirow[t]{2}{*}{ Location } & \multirow[t]{2}{*}{ Pop. ${ }^{(c)}$} & \multicolumn{6}{|c|}{ EDE $\left(10^{-6} \mathrm{mrem} /\right.$ Year $)$ Due to Releases from: } & \multirow{2}{*}{$\begin{array}{c}\text { Collective } \\
\text { EDE } \\
\text { man-mrem }\end{array}$} \\
\hline & & $\begin{array}{l}\text { Area } 12^{(a)} \\
\text { Tritium }\end{array}$ & $\begin{array}{l}\text { Other } \\
\text { Areas }^{(b)}\end{array}$ & $\begin{array}{c}\text { YUCCA Flat } \\
\text { Area } 3^{(a)} \quad \text { Area } 9^{(a)} \\
\end{array}$ & $\begin{array}{l}\text { Area } 5^{(\boldsymbol{s})} \\
\text { RWMS }\end{array}$ & $\begin{array}{c}\text { Area } 20 \\
\text { Tritium }\end{array}$ & $\begin{array}{l}\text { Total EDE } \\
10^{-3} \mathrm{mrem} \\
\end{array}$ & \\
\hline Alamo & 1000 & . & 9900 & & & & 9.9 & 9.9 \\
\hline Amargosa Valley & 1200 & 25 & 58000 & 9500 & 4.5 & 250 & 71 & 85 \\
\hline Ash Meadows & 10 & & 14000 & 4000 & 4.2 & & 18 & 0.18 \\
\hline Ash Springs & 70 & & 1900 & & & & 1.9 & 0.13 \\
\hline Beatty & 1500 & 23 & 78000 & 9500 & 4.5 & 400 & 93 & 140 \\
\hline Clark Station & 2 & & 12000 & & & & 12 & 0.024 \\
\hline Crystal & 45 & 39 & 57000 & 6500 & 4.5 & & 67 & 3.0 \\
\hline Death Valley Jct. & 7 & & & & 4.3 & & 0.0043 & $3.0 \times 10^{-5}$ \\
\hline Desert Game Range & 4 & & & & 4.1 & & 0.0041 & $1.6 \times 10^{-5}$ \\
\hline Goldfield & 600 & & 4400 & & & & 4.4 & 2.6 \\
\hline Hiko & 103 & & 1800 & & & & 1.8 & 0.18 \\
\hline Indian Springs & 1200 & 53 & 23000 & 1500 & 4.5 & & 29 & 35 \\
\hline Lathrop Wells & 30 & 28 & 84000 & 12000 & 4.7 & 270 & 100 & 3.0 \\
\hline Lida Junctlon & 8 & & 14000 & & & 370 & 14 & 0.11 \\
\hline Medlin's Ranch & $\underline{\underline{2}}$ & 28 & 37000 & 5500 & 4.2 & 220 & 45 & 0.09 \\
\hline
\end{tabular}

(a) Emissions calculated from surveillance data.

(b) Emissions calculated from engineering data.

(c) Population at that location for 1996.

(d) Blank spaces represent locations farther than $80 \mathrm{~km}$ from the source for the column. 
Table 5.0 (Effective Dose Equivalent Tabulation by Location [Multiply mrem by $10^{-2}$ for Equivalent mSv Units - $1996^{(\mathrm{d})}$ ], cont.)

\begin{tabular}{|c|c|c|c|c|c|c|c|c|}
\hline \multirow[t]{2}{*}{ Location } & \multirow[t]{2}{*}{ Pop..$^{(c)}$} & \multicolumn{6}{|c|}{ EDE $\left(10^{-6} \mathrm{mrem} /\right.$ year $)$ Due to Releases from: } & \multirow{2}{*}{$\begin{array}{l}\text { Collective } \\
\text { EDE } \\
\text { man-mrem }\end{array}$} \\
\hline & & $\begin{array}{l}\text { Area } 12^{(a)} \\
\text { Tritium }\end{array}$ & $\begin{array}{l}\text { Other } \\
\text { Areas }^{(0)}\end{array}$ & $\begin{array}{c}\text { YUCCA Flat } \\
\text { Area } 3^{(\mathbf{a})} \quad \text { Area } 9^{(a)} \\
\end{array}$ & $\begin{array}{l}\text { Area } 5 \text { (a) } \\
\text { RWMS }\end{array}$ & $\begin{array}{c}\text { Area } 20 \\
\text { Tritium } \\
\end{array}$ & $\begin{array}{l}\text { Total EDE } \\
10^{-3} \mathrm{mrem}\end{array}$ & \\
\hline Mt. Charleston & 500 & & & & 4.1 & & 0.0041 & $2.0 \times 10^{-3}$ \\
\hline Pahrump & 20000 & & & & 4.2 & & 0.0042 & 0.084 \\
\hline Penoyer Farm & 16 & 28 & 42000 & 4400 & & 240 & 49 & 0.78 \\
\hline Rachel & 105 & 28 & 37000 & 1900 & & 220 & 43 & 4.52 \\
\hline Sarcobatus Flats & 40 & 37 & 28000 & 1200 & & 460 & 30 & 1.2 \\
\hline S NV Corr. Ctr & 2000 & & 2500 & 1100 & 4.3 & & 3.6 & 7.2 \\
\hline Springdale & 20 & 25 & 92000 & 9500 & 4.3 & 460 & 110 & 2.2 \\
\hline Stateline \& Area & 70 & & 14000 & 3200 & 4.3 & & 17 & 1.2 \\
\hline Stone Cabin Rn. & 6 & & 9500 & & & & 9.5 & 0.057 \\
\hline Tonopah & 3400 & & 8000 & 3800 & & & 12 & 40 \\
\hline Twin Springs Rn. & 6 & & 2400 & & & & 2.4 & 0.014 \\
\hline U.S. Ecology & 35 & 25 & 61000 & 8500 & 4.6 & 300 & 75 & 2.6 \\
\hline
\end{tabular}

\begin{tabular}{|c|c|c|c|c|c|c|}
\hline \multirow{3}{*}{$\begin{array}{r}\text { Total Population - } 32,210 \\
\text { Maximally Exposed Individual: } \\
0.11 \text { mrem } \\
\text { Location of Maximally Expose } \\
\text { Springdale, Nevada }\end{array}$} & \multicolumn{5}{|c|}{ Maximum Individual Dose Calculated for Each Release Point $-10^{-3} \mathrm{mrem}$} & \multirow{3}{*}{$\begin{array}{c}\text { Total Person-rem: } \\
0.34\end{array}$} \\
\hline & Area 12 & Other Areas & YUCCAFlat & Area 5 & Area 20 & \\
\hline & 0.053 & 92 & 19 & 0.005 & 0.46 & \\
\hline
\end{tabular}

(a) Emissions calculated from surveillance data.

(b) Emissions calculated from engineering data.

(c) Population at that location for 1996.

(d) Blank spaces represent locations farther than $80 \mathrm{~km}$ from the source for the column. 


\section{Certification}

I certify under penalty of law that I have personally examined and am familiar with the information submitted herein and based on my inquiry of those individuals immediately responsible for obtaining the information, I believe that the submitted information is true, accurate, and complete. I am aware that there are significant penalties for submitting false information including the possibility of fine and imprisonment. See 18 U.S.C. 1001.

Name: Gerald W. Johnson, Manager, Nevada Operations Office

Signature:

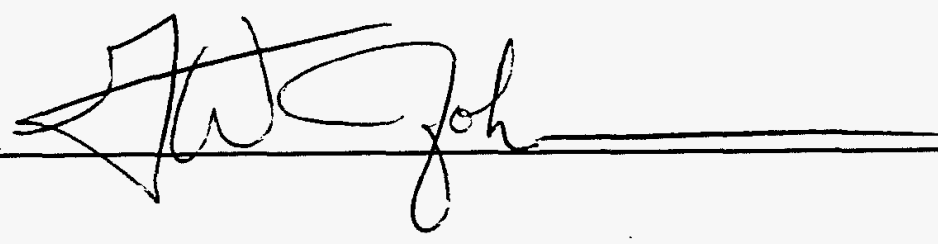




\section{SECTION IV \\ ADDITIONAL INFORMATION}

\section{NEW CONSTRUCTION/MODIFICATION ACTIVITIES AT THE NTS}

No new construction or modification to existing permanent structures that emit radionuclides during normal operations was completed at the NTS during CY96.

\section{UNPLANNED RELEASES DURING THIS CY}

All releases on the NTS during this CY were operational. There was a detectable release at the Atlas Facility located in North Las Vegas that was a continuance of a 1995 incident (see Appendix A for a description).

\section{SOURCES OF DIFFUSE OR FUGITIVE EMISSIONS}

These sources included evaporation from containment ponds that receive liquid effluents from E tunnel in Area 12 and from groundwater characterization wells in Area 20; resuspension of ${ }^{239+240} \mathrm{Pu}$ from soil deposits on the NTS in Areas 3, 9, and safety test areas; and seepage of tritium from packages buried at the RWMS-5 (see Appendix $\mathrm{G}$ ).

The EDE to the MEI was principally due to the diffuse sources. The EDE from point sources was negligible. The methods used to determine the emissions from these diffuse sources are described in the appendices. 
FIGURES 


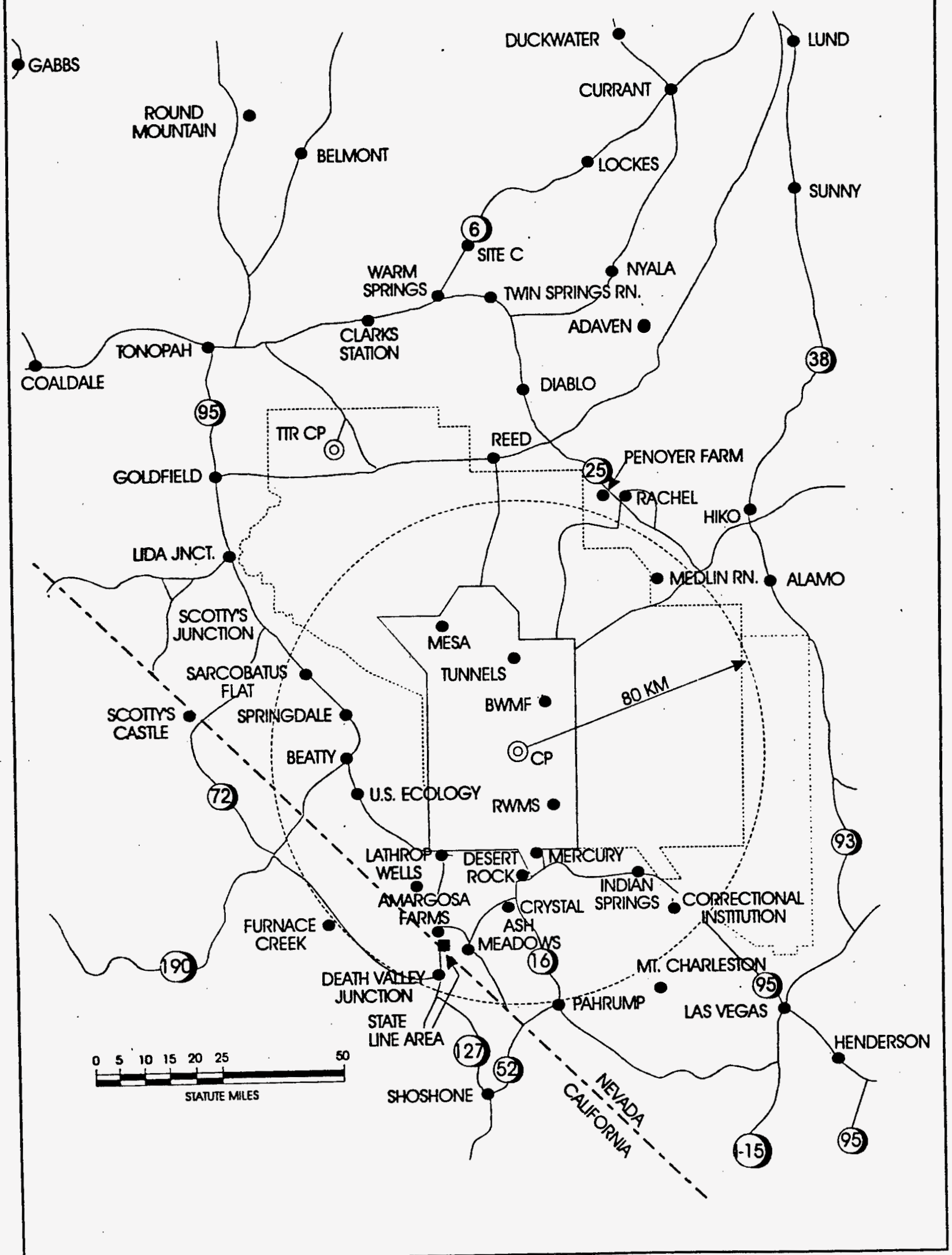

Figure 1.0 Map of the Area Around the NTS 


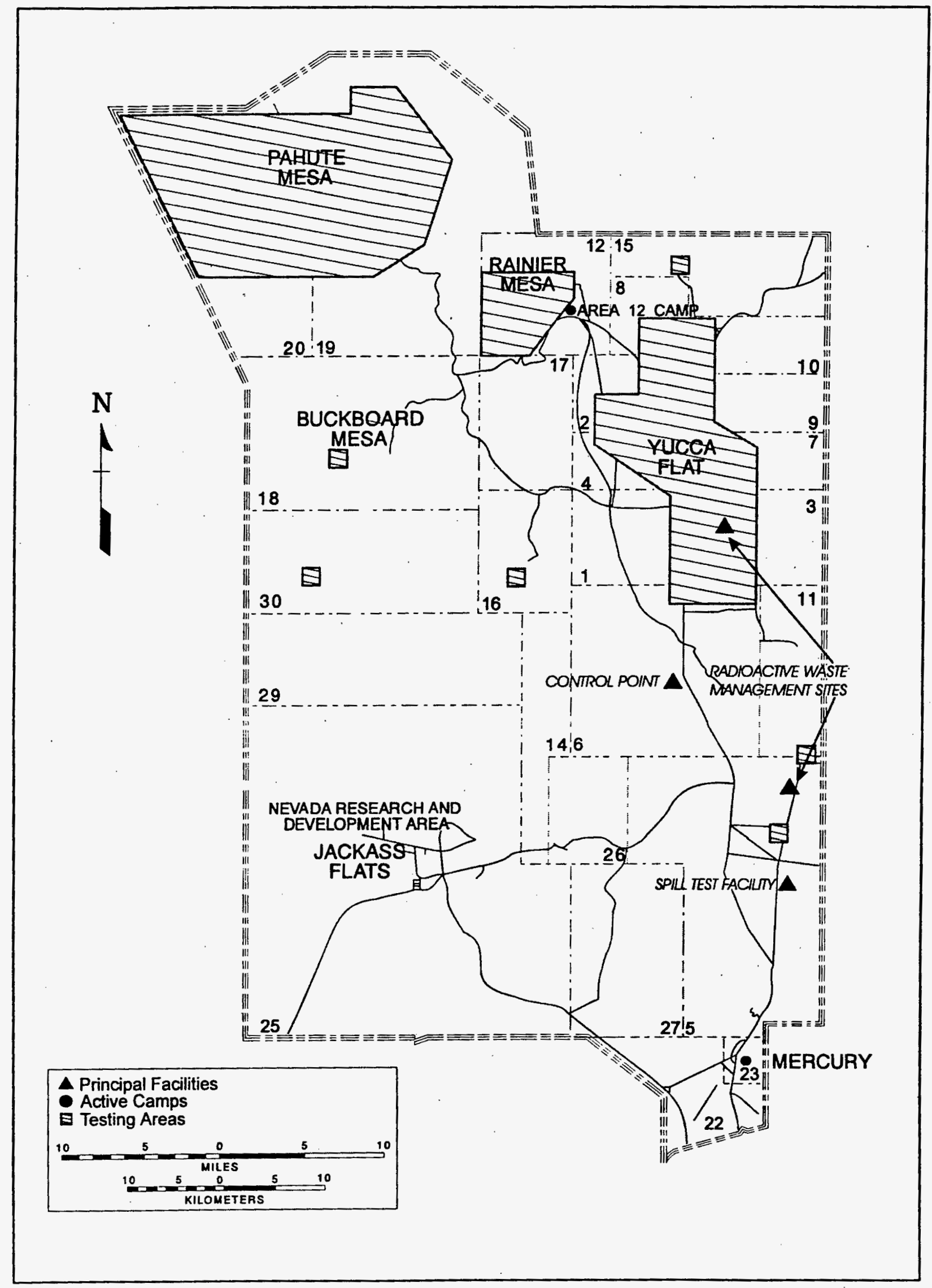

Figure 2.0 Nuclear Testing Areas on the NTS 

How

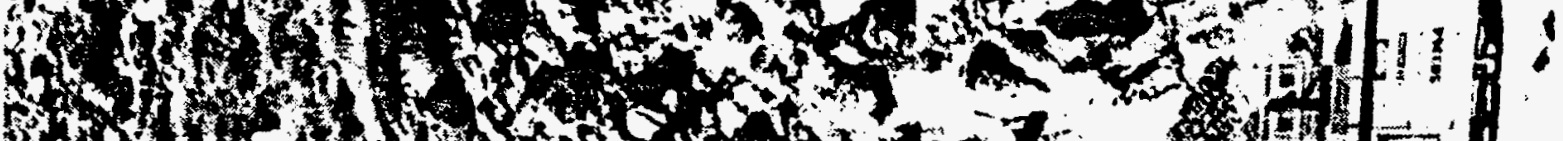

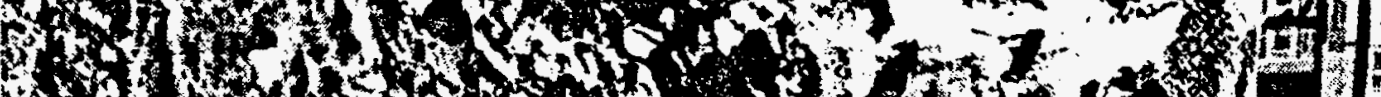

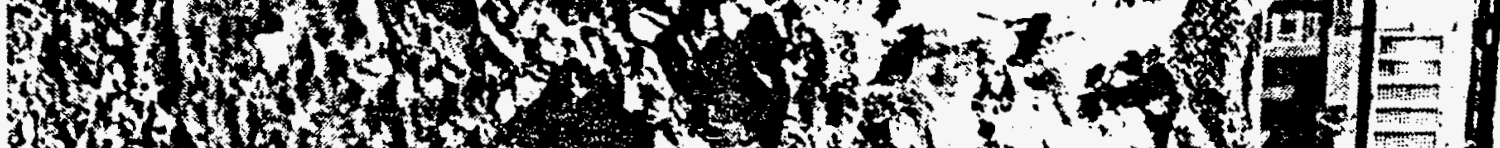

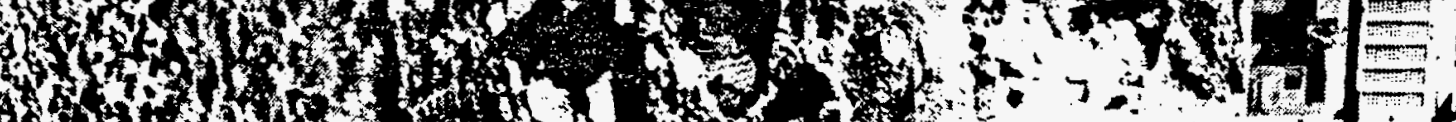

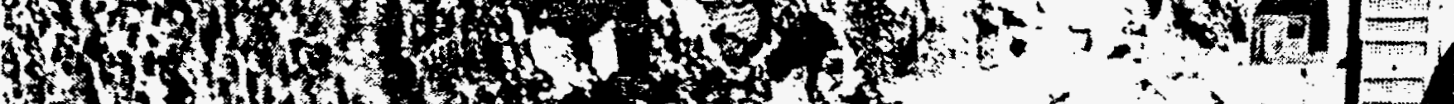

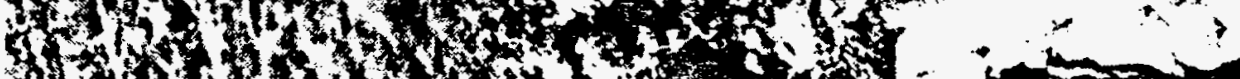

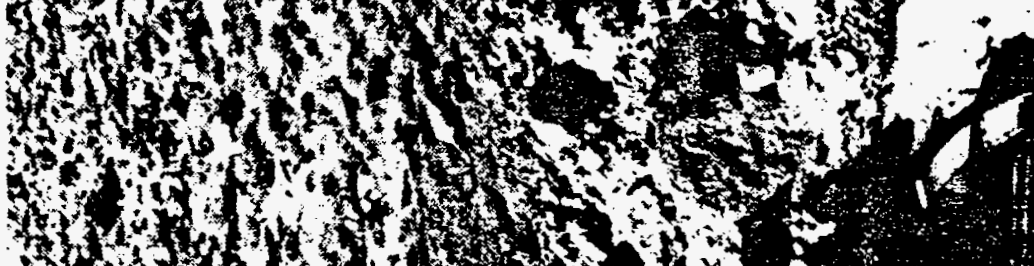
1)

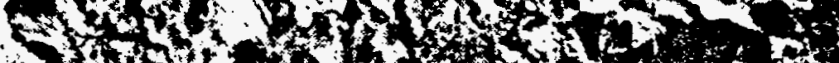
HW (1)

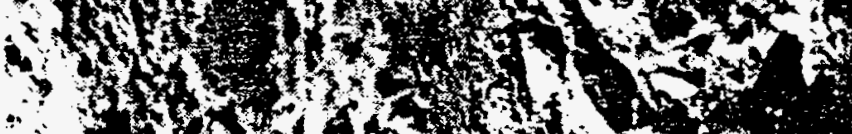

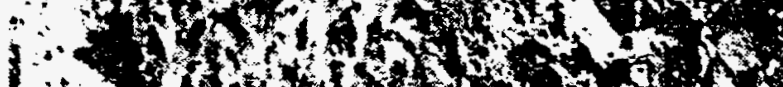

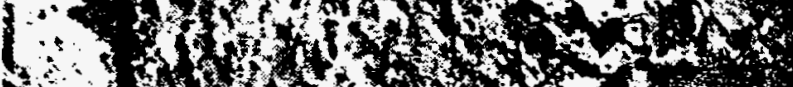

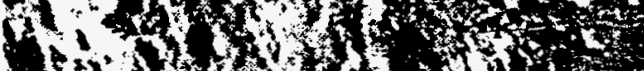

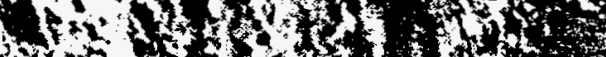
W Now 10

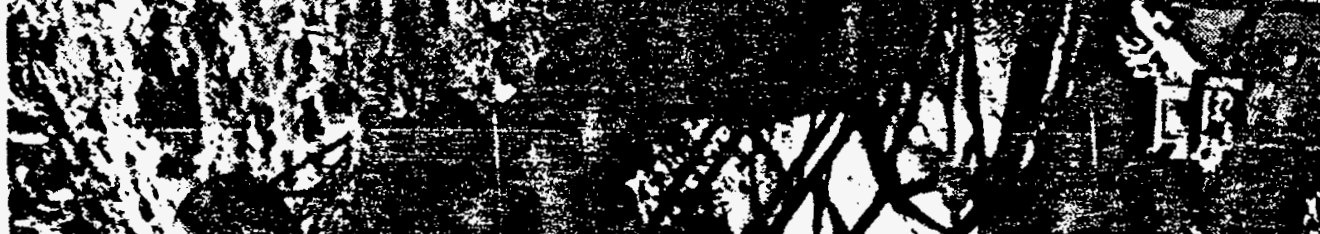

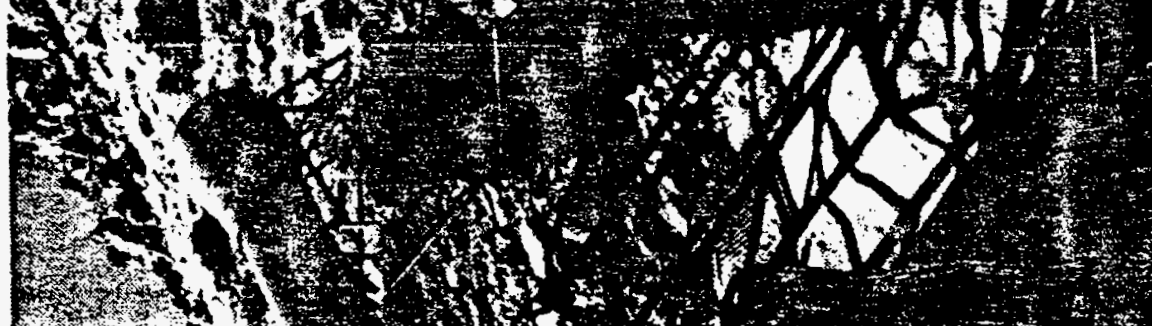

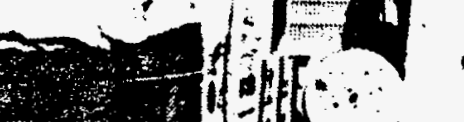

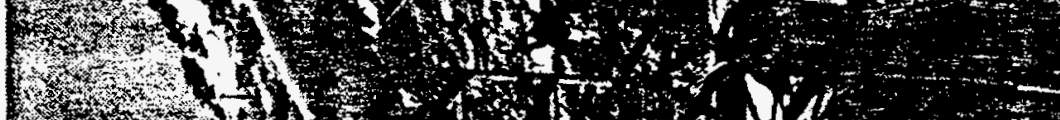

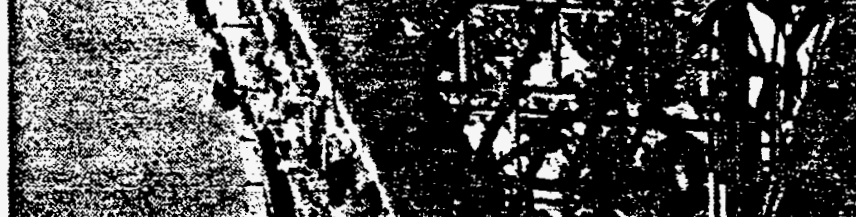
-1. 1 .

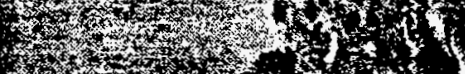

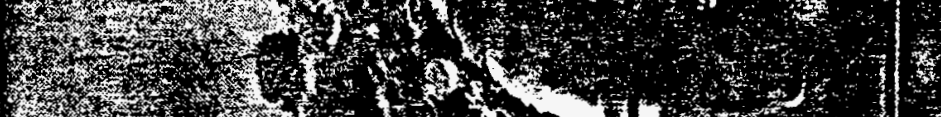
23. . $1 .-1+3$ 4

Figure 3.0 Photograph of a Tunnel Portal 


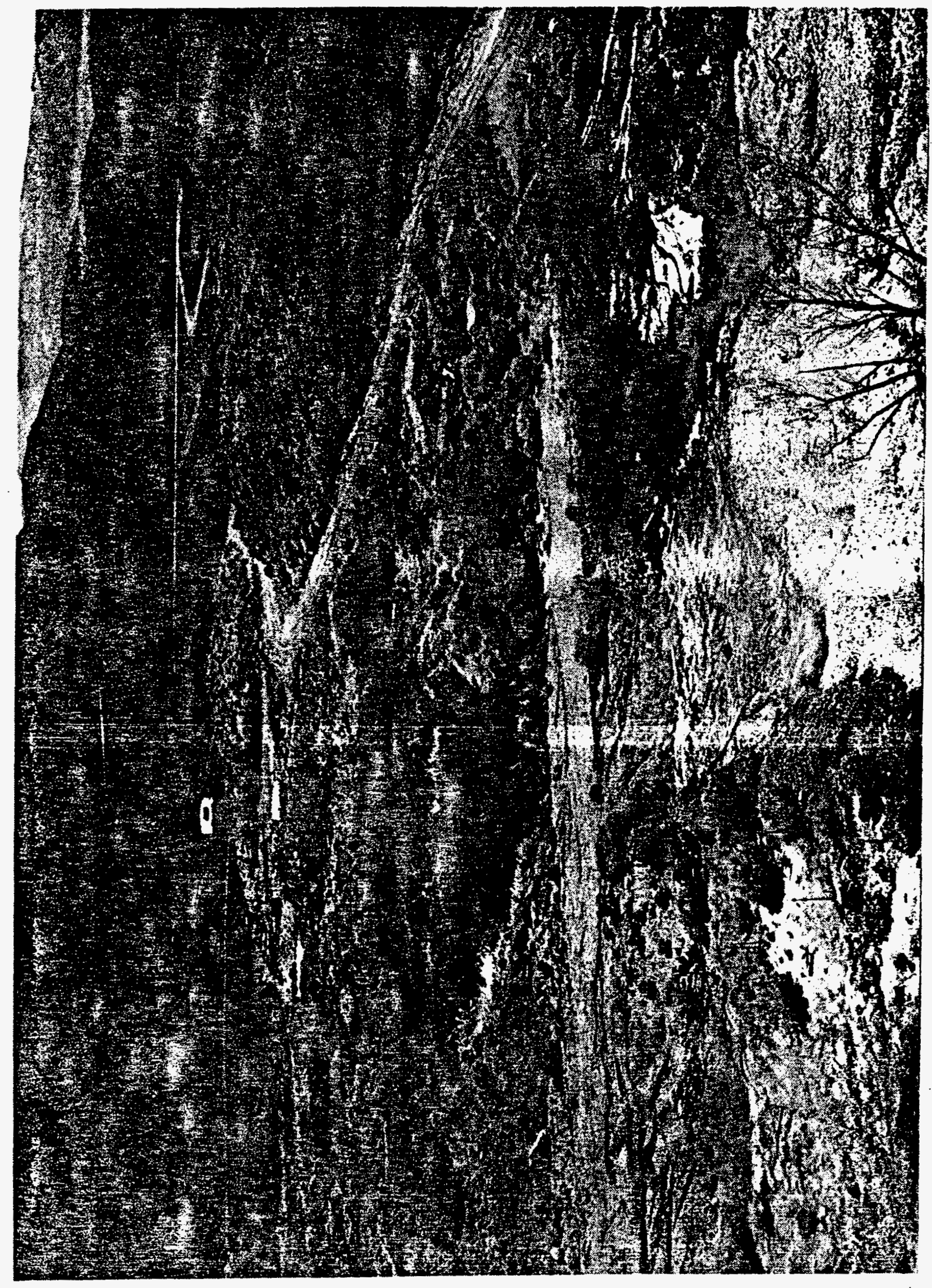

Figure 4.0 Photograph of Tunnel Containment Ponds 


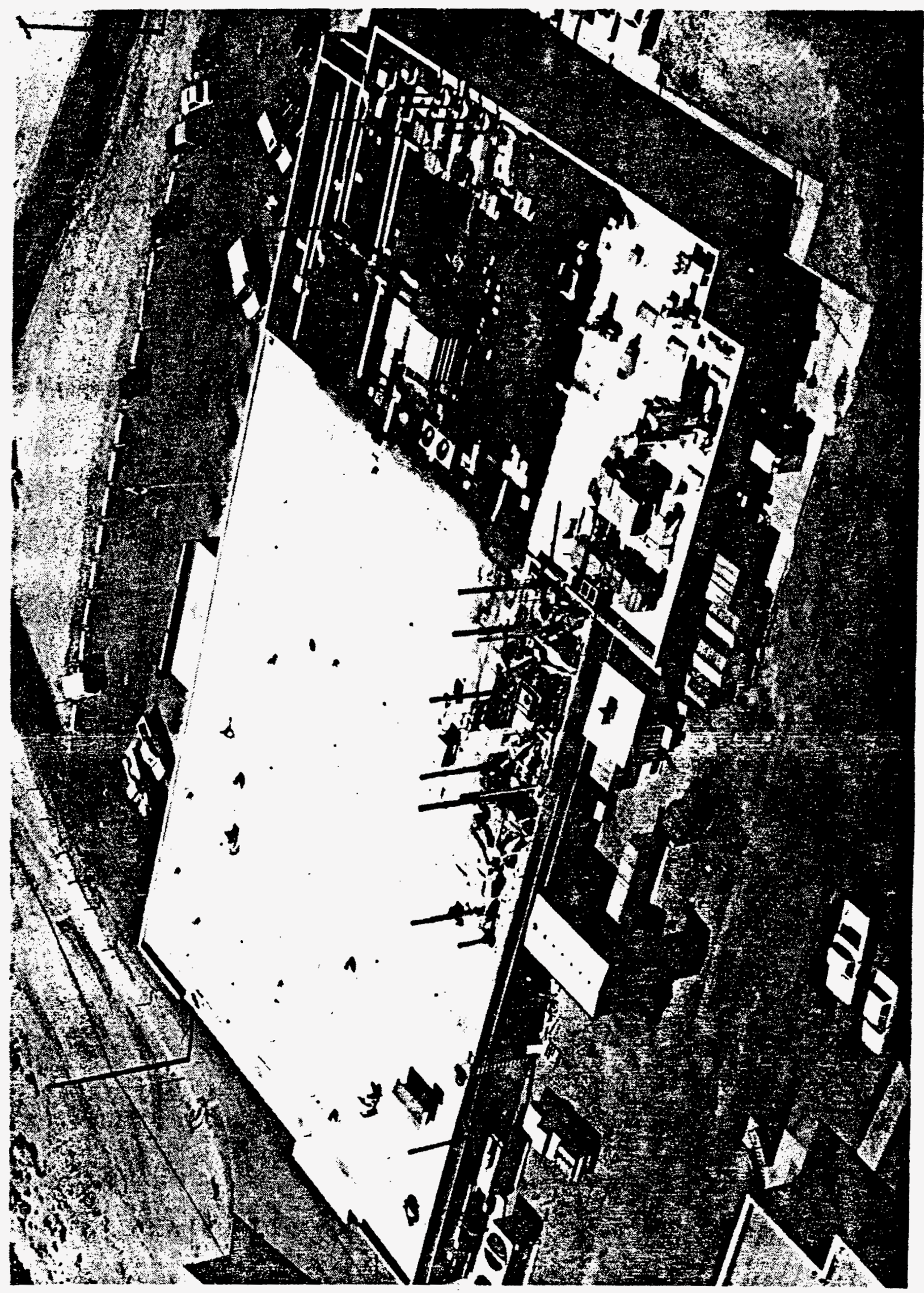

Figure 5.0 Photograph of the Building 650 Hood Ventilation Stacks Seen from Above 


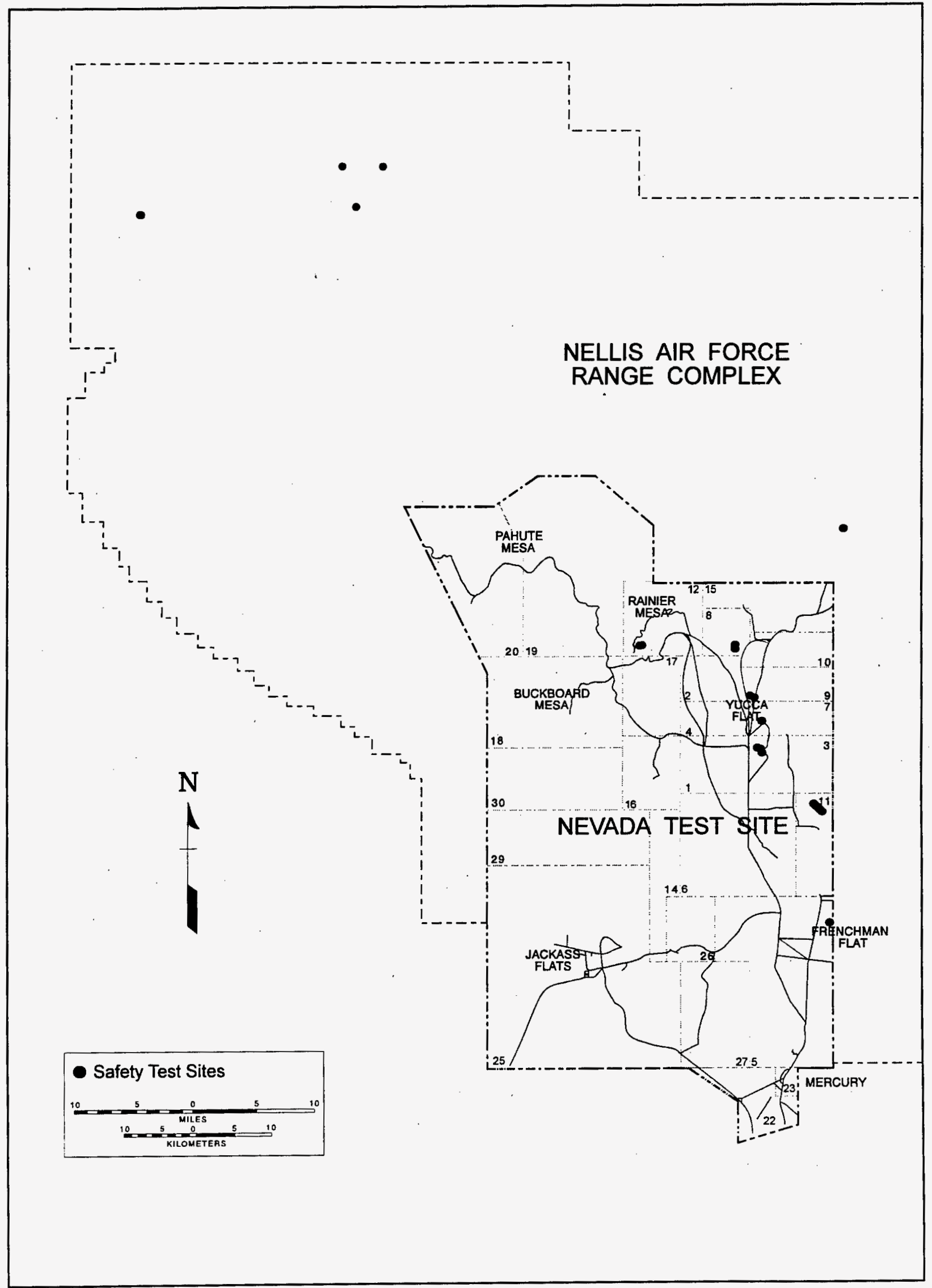

Figure 6.0 Location of Nuclear Device Safety Test 
APPENDICES 


\section{APPENDIX A \\ PUBLIC DOSE CALCULATIONS FOR THE \\ ATLAS TRITIUM INCIDENT}

\section{ENVIRONMENTAL SURVEILLANCE}

As reported in 1995 NESHAP's report, a container of tritium foils was opened in the Atlas Facility at the North Las Vegas Operations area that emitted about $0.5 \mathrm{Ci}$ into a basement area used as a fixed radiation source range. Environmental surveillance efforts began with notification on Friday, July 14, 1995, that the tritium leak had occurred. Environmental surveillance personnel chose three sites for placement of air samplers that would collect atmospheric moisture samples for subsequent analysis of tritium (as HTO) concentration in air. The sampler sites chosen included one sampler in the direct downwind path from the Atlas (Building A-1) vent pipe. Later, a tritium-in-air sampler was installed in the basement, so that progress on cleanup of the spill could be monitored. After cleanup began, the environmental samplers were removed, but the basement air sampler continued operation.

Basement sampling continued until October 1996, and the results indicated continued emission of tritium from absorbent surfaces in the facility. Therefore, a calculation was performed to estimate an EDE to the MEI offsite. As reported last year, an aerial photo of the North Las Vegas Operations area was used to locate the nearest building or residence to the Atlas facility and a 16-sector array centered on that facility was drawn. It was found that the nearest offsite structure was an industral building, $100 \mathrm{~m}$ northwest of the Atlas facility vent pipe.

The 1996 EDE for offsite locations was obtained by using the air sampler results to calculate a total emission from the facility. The method is as follows:

- The 1995 data contained results for the environmental samplers and the basement sampler, so a ratio was constructed relating basement air results to the environmental sampler results.

- This ratio was used to calculate an average concentration for the nine months of sampling at the location where the environmental sampler was in 1995.

- The dose conversion factor for tritium inhalation $\left(6.4 \times 10^{-8} \mathrm{mrem} / \mathrm{pCi}\right)$, multiplied by 1.5 to correct for skin absorption, and by $8,400 \mathrm{~m}^{3} / \mathrm{yr}$ breathed by a normal adult were used to obtain an EDE for that sampler location.

- A $1 \mathrm{mCi}$ release was used in CAP88PC, D stability, Las Vegas wind data, to obtain an EDE at the location of the air sampler.

- Divide the calculated EDE from the monitoring data as in step 3 by the EDE/mCi from CAP88PC in step four to obtain an estimated release in $\mathrm{mCi}$.

As an example of this calculation, use the calculated average data from Table A-1 for the North Las Vegas sampler $\left(4.13 \times 10^{-12} \mu \mathrm{Ci} / \mathrm{mL}=4.13 \mathrm{pCi} / \mathrm{m}^{3}\right)$ :

$$
\begin{gathered}
E D E=4.13 \mathrm{pCilm} \mathrm{m}^{3} \times 1.5 \times 8400 \mathrm{~m}^{3} / \mathrm{yr} \times 6.4 \times 10^{-8} \mathrm{mrem} / \mathrm{pCi} \\
=0.0033 \mathrm{mrem} .
\end{gathered}
$$

A CAP88PC run with $1 \mathrm{mCi}$ release yields $4.8 \times 10^{-5} \mathrm{mrem}$ at the sampler position.

$\therefore$ the estimated effluent would be: $\frac{0.0033 \mathrm{mrem}}{4.8 \times 10^{-5} \mathrm{mrem} / \mathrm{mCi}}$

$=69 \mathrm{mCi}$. 
However, since the measurement period was only for nine months in 1996, the emission would be nine-twelfths of the annual emission or $52 \mathrm{mCi}$.

The CAP88PC run with a $1 \mathrm{mCi}$ emission of tritium also yielded data for other locations around the site, such as the data for the nearest building of $4.8 \times 10^{-6} \mathrm{mrem} / \mathrm{mCi}$. So, assuming there is a person at that location, that individual would be the $\mathrm{MEI}$, and the EDE would be $52 \mathrm{mCi} \times 4.8 \times 10^{-6} \mathrm{mrem} / \mathrm{mCi}=2.5 \times 10^{-4} \mathrm{mrem}$ or $0.25 \mu \mathrm{rem}$.

\section{CONCLUSION}

The best estimate of offsite EDE to the MEI was $0.25 \mu$ rem. For comparison, the NESHAP: Radionuclides specifies a limit of 10 mrem to the $\mathrm{MEI}$ or about 40,000 times that calculated. Also, the EDE calculated assumes the person resides at the nearest building location year around. That building is a workplace, so the dose to an occupant would be much less.

Table A.1 HTO in Air Results for the North Sampler, Atlas Facility - 1996

Tritium Calculation for the Atlas Facility

Date

\section{Collected}

$01 / 25 / 96$

$02 / 08 / 96$

$02 / 22 / 96$

$03 / 07 / 96$

$03 / 21 / 96$

$04 / 04 / 96$

$04 / 18 / 96$

$05 / 02 / 96$

05/16/96

$05 / 30 / 96$

$06 / 13 / 96$

$06 / 27 / 96$

$07 / 12 / 96$

$07 / 26 / 96$

$07 / 26 / 96$

$08 / 09 / 96$

$08 / 22 / 96$

$09 / 05 / 96$

$09 / 20 / 96$

10/03/96

\section{Ratio ${ }^{(a)}$}

$.1 .87 \times 10^{-04}$

$1.87 \times 10^{-04}$

$1.87 \times 10^{-04}$

$1.87 \times 10^{-04}$

$1.87 \times 10^{-04}$

$1.87 \times 10^{-04}$

$1.87 \times 10^{-04}$

$1.87 \times 10^{-04}$

$1.87 \times 10^{-04}$

$1.87 \times 10^{-04}$

$1.87 \times 10^{-04}$

$1.87 \times 10^{-04}$

$1.87 \times 10^{-04}$

$1.87 \times 10^{-04}$

$1.87 \times 10^{-04}$

$1.87 \times 10^{-04}$

$1.87 \times 10^{-04}$

$1.87 \times 10^{-04}$

$1.87 \times 10^{-04}$

$1.87 \times 10^{-04}$

Annual Average

A-1 Basement
Concentration

$2.86 \times 10^{-08}$

$2.92 \times 10^{-08}$

$2.68 \times 10^{-08}$

$3.49 \times 10^{-08}$

$2.59 \times 10^{-08}$

$1.98 \times 10^{-08}$

$1.87 \times 10^{-08}$

$1.85 \times 10^{-08}$

$2.07 \times 10^{-08}$

$2.18 \times 10^{-08}$

$1.81 \times 10^{-08}$

$1.94 \times 10^{-08}$

$2.52 \times 10^{-08}$

$2.20 \times 10^{.08}$

$2.22 \times 10^{-08}$

$1.82 \times 10^{-08}$

$1.56 \times 10^{-08}$

$1.54 \times 10^{-08}$

$1.74 \times 10^{-08}$

$1.38 \times 10^{-08}$
Calculated

Concentration

$5.35 \times 10^{-12}$

$5.46 \times 10^{-12}$

$5.01 \times 10^{-12}$

$6.53 \times 10^{-12}$

$4.84 \times 10^{-12}$

$3.70 \times 10^{-12}$

$3.50 \times 10^{-12}$

$3.46 \times 10^{-12}$

$3.87 \times 10^{-12}$

$4.08 \times 10^{-12}$

$3.38 \times 10^{-12}$

$3.63 \times 10^{-12}$

$4.71 \times 10^{-12}$

$4.11 \times 10^{-12}$

$4.15 \times 10^{-12}$

$3.40 \times 10^{-12}$

$2.92 \times 10^{-12}$

$2.88 \times 10^{-12}$

$3.25 \times 10^{-12}$

$2.58 \times 10^{-12}$

$4.13 \times 10^{-12}$

(a) Ratio of N Sampler Data to Basement Sampler Data based on 1995 Results. 


\section{APPENDIX B \\ EMISSIONS FROM CONTAINMENT PONDS}

\section{EMISSION FROM TUNNELS, PONDS, ETC.}

Effluent water from the Area 12 tunnel complexes and the containment ponds that receive that water were sampled once each month. These water samples are analyzed for radionuclides by gamma spectroscopy, for gross beta, and for tritium (as HTO). Less frequently, other samples. are collected for analysis of plutonium and strontium. The total amount of radioactive liquid effluent from the tunnels is calculated from the concentration of radionuclides in the water and the total volume of water discharged during the year. The flow rate of water discharged from the tunnels was measured weekly.

In order to calculate doses using CAP88-PC, an airborne source term must be known. As described above, the total liquid effluent volume is measured and the radionuclide concentrations are determined from analysis of monthly samples. By assuming that the total amount of tritium (as HTO) measured in the liquid effluent during the year evaporates and becomes airborne, a conservative estimate of the airborne source term is obtained. It is unlikely that this is a true source term for the containment ponds, but it is an upper limit of the effluents which could be released. The fact that the concentration of tritium in the ponds and their surface areas, at the beginning and end of the year, have been relatively constant ${ }^{(3)}$ lends credence to this calculation. The tunnels are being sealed, so the effluents have decreased. E Tunnel is now the only source of HTO to tunnel ponds. The Ci of HTO discharged are shown in Table B-1.

During 1995, three characterization wells were drilled near an underground cavity created by a nuclear explosive test. Water was continually pumped from the wells into lined containment ponds. Tritium measurements were made on water samples taken from the conduit leading to the ponds. A continued, but smaller, discharge occurred in 1996, and its contribution is also given in Table B-1.

Table B.1 Tritium Water Effluents in 1996

Location

Area 12, E Tunnel

Area 20, ER-20 -5 Wells

Area 20, ER-20-6 Wells

Area 5, Water to Air Experiment

Total Effluent
Area $\left(\mathrm{m}^{2}\right)$

336
Total ${ }^{3} \mathrm{H}$ Discharged (Ci)

10.6

111.5

8.2

0.014

130.3

The MEI for the Area 12 emission resides in Indian Springs, Nevada, and would receive an EDE of $0.053 \mu \mathrm{rem}\left(0.53 \times 10^{-6} \mathrm{mSv}\right)$.

(3) For example: E Tunnel Pond

$\underline{\operatorname{Result}(\bar{X})}$

$5.65 \times 10^{-4}$

$4.91 \times 10^{-4}$
$\underline{Q t r} / Y r$.

1st

4th 
In 1996, another set of wells was drilled in Area 20. HTO was also pumped from these wells. An estimate of the HTO pumped in 1996 is also given in Table B-1.

A final source of HTO from water evaporation occurred during a transfer experiment conducted during the first half of 1996. A large tank was partially filled with HTO, and air was blown through the water to determine a transfer coefficient for HTO from water to air. The total curies of HTO evaporated are shown in Table B-1.

The $\mathrm{MEl}$ for the Area 20 emission resides in Sarcobatus Flats and would receive an EDE of $0.46 \mu \mathrm{rem}\left(4.6 \times 10^{-6} \mathrm{mSv}\right)$.

A calculation was performed in the 1995 NESHAP report to estimate tritium emission from the E Tunnel Pond during 1994, using the methods for estimating diffuse emissions, as suggested in the EPA report dated July 1994 for comparison with the above method. It was concluded that the EPA method seriously underestimated the effluent source term, so the calculation was not repeated herein. For reference, the equation used for that calculation is repeated below. Use of the equation resulted in a source term of $2.4 \mathrm{Ci}$, when total evaporation would yield a more conservative estimate of the source term as $260 \mathrm{Ci}$.

\section{EVAPORATION OF WATER - EPA'S RECOMMENDATION}

The following is the formula on page 26 of the EPA report that is recommended for estimating water evaporation from a circular pool:

$$
E=\frac{20.73 \times P_{s} \times A^{0.9} \times U^{0.8}}{T^{1.47}}
$$

where $\quad E=$ evaporation rate, $g / s$

$A=$ surface area of pond, $\mathrm{m}^{2}$

$P_{\mathrm{s}}=$ equilibrium water vapor pressure at

$\mathrm{U}=$ wind speed, $\mathrm{m} / \mathrm{s}$ ambient temp., $\mathrm{mm} \mathrm{Hg}$

$\mathrm{T}={ }^{\circ} \mathrm{K}={ }^{\circ} \mathrm{C}+273.2$ 


\section{APPENDIX C \\ RADIONUCLIDE INVENTORY OF \\ RADIOANALYTICAL LABORATORIES}

\section{BN LABORATORY}

The inventory of radionuclides in the Analytical Services Laboratory located in Building 650, at the NTS, was estimated by inventorying the standards, check sources, and tracer solutions. The activity contained in these sources was orders of magnitude above that contained in samples (based on data collected in previous years), so they are listed in Table C.1.

From the inventory, only three of the items are volatile and may become a source of air emissions. These are ${ }^{3} \mathrm{H}$ (as HTO), ${ }^{129} \mathrm{I}$, and ${ }^{85} \mathrm{Kr}$ and are listed in Table 2.0 above. All of the standards and solutions are compared to the possession limits set forth in Title 40 C.F.R. 61, Appendix $E$, and all are less than one percent of those limits as shown in the last column of Table C.1.

\section{LANL LABORATORY}

In previous years, this laboratory maintained standards of radioactivity containing ${ }^{133} \mathrm{Xe},{ }^{131} \mathrm{I}$, and ${ }^{3} \mathrm{H}$. Due to the test moratorium that began in 1992, the need for standards was reduced and the only standard of significance for airborne emission maintained in 1995 was $500 \mu \mathrm{Ci}$ of tritium $\left(5 \times 10^{-4} \mathrm{Ci}\right)$. This quantity is assumed to evaporate over the course of the year and adds to the amount listed above for $B N$. 
Table C.1 Building 650 Health Physics Laboratory Inventory Compared to NESHAP

\begin{tabular}{|c|c|c|c|}
\hline Radionuclide & 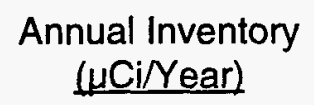 & $\begin{array}{c}\text { Possession Limit } \\
\text { (Ci/Year Liquid Form) }\end{array}$ & Ratio \% \\
\hline $\mathrm{H}-3$ & 202.000 & 15000.000 & $1.3 \times 10^{-6}$ \\
\hline C- 14 & 5.100 & 290.000 & $1.8 \times 10^{-6}$ \\
\hline $\mathrm{Fe}-55$ & 6.400 & 140.000 & $4.6 \times 10^{-6}$ \\
\hline $\mathrm{Cr}-51$ & 0.000 & 63.000 & 0.0 \\
\hline Co-57 & 0.075 & 1.600 & $4.7 \times 10^{-6}$ \\
\hline Co-60 & 0.700 & 0.016 & $4.4 \times 10^{-3}$ \\
\hline $\mathrm{Ni}-63$ & 6.490 & 140.000 & $4.6 \times 10^{-6}$ \\
\hline $\mathrm{Kr}-85$ & 18600.000 & 840.000 & $2.2 \times 10^{-3}$ \\
\hline Sr-85 & 0.036 & 1.900 & $1.9 \times 10^{-6}$ \\
\hline Sr-89 & 0.190 & 21.000 & $9.0 \times 10^{-7}$ \\
\hline Sr-90 & 0.350 & 0.520 & $6.7 \times 10^{-5}$ \\
\hline$Y-88$ & 0.290 & 0.250 & $1.2 \times 10^{-4}$ \\
\hline Tc-99 & 6.940 & 9.000 & $7.7 \times 10^{-5}$ \\
\hline Cd-109 & 3.200 & 5.000 & $6.4 \times 10^{-5}$ \\
\hline$S n-113$ & 0.430 & 1.900 & $2.3 \times 10^{-5}$ \\
\hline $1-129$ & 1.510 & 0.260 & $5.8 \times 10^{-4}$ \\
\hline $1-131$ & 0.000 & 6.700 & 0.0 \\
\hline $\mathrm{Te}-123$ & 0.045 & 1.200 & $1.3 \times 10^{-6}$ \\
\hline Cs-137 & 0.720 & 0.023 & $3.1 \times 10^{-3}$ \\
\hline $\mathrm{Pb}-210$ & 0.500 & 0.055 & $9.1 \times 10^{-4}$ \\
\hline Ra-226 & 10.100 & 0.006 & $1.8 \times 10^{-1}$ \\
\hline Ra-228 & 0.015 & 0.013 & $1.2 \times 10^{-4}$ \\
\hline Th-229 & 0.050 & 0.001 & $1.0 \times 10^{-2}$ \\
\hline Th-230 & 0.008 & 0.003 & $2.5 \times 10^{-4}$ \\
\hline Th-Nat & 0.009 & & -- \\
\hline U-232 & 0.013 & 0.001 & $1.0 \times 10^{-3}$ \\
\hline U-Nat & 0.120 & 0.009 & $1.4 \times 10^{-3}$ \\
\hline Np-237 & 0.013 & 0.002 & $7.2 \times 10^{-4}$ \\
\hline Pu-238 & 0.055 & 0.003 & $2.2 \times 10^{-3}$ \\
\hline Pu-241 & 0.040 & 0.130 & $3.1 \times 10^{-5}$ \\
\hline Pu-242 & 0.006 & 0.003 & $2.4 \times 10^{-4}$ \\
\hline Am-241 & 1.420 & 0.002 & $6.2 \times 10^{-2}$ \\
\hline Am-243 & 0.001 & 0.002 & $2.6 \times 10^{-5}$ \\
\hline $\mathrm{Cm}-244$ & 0.000 & 0.004 & 0.0 \\
\hline Alpha Emitters ${ }^{(a)}$ & 12.000 & 0.0042 & $2.8 \times 10^{-1}$ \\
\hline Beta Emitters ${ }^{(b)}$ & 15.000 & 0.520 & $2.9 \times 10^{-3}$ \\
\hline Gamma Emitters ${ }^{(c)}$ & 6 & 0.016 & $3.8 \times 10^{-2}$ \\
\hline
\end{tabular}

(a) Alpha emitters include Th, $U$, and transuranics. The possession limit is that for ${ }^{244} \mathrm{Cm}$ (Title 40 C.F.R. 61 Appendix E, Table 1).

(b) Beta emitters include the sum of ${ }^{14} \mathrm{C},{ }^{36} \mathrm{Cl},{ }^{89} \mathrm{Sr},{ }^{90} \mathrm{Sr},{ }^{99} \mathrm{~T}$, and ${ }^{155} \mathrm{Eu}$ and are compared to the ${ }^{90} \mathrm{Sr}$ annual possession quantity (Title 40 C.F.R. 61 Appendix E, Table 1).

(c) Gamma emitters is the sum of cobalt, chromium, and the mixed gamma sources, and the possession limit is for ${ }^{60} \mathrm{Co}$ (Title 40 C.F.R. 61 Appendix E, Table 1). 


\section{APPENDIX D \\ DIFFUSE SOURCE ATMOSPHERIC TRITIUM EMISSIONS}

\section{BACKGROUND INFORMATION}

Environmental monitoring for tritium in atmospheric moisture was conducted at 16 locations on the NTS for varying amounts of time. There were eight air samplers around the RWMS perimeter in RWMS-5, because many curies of ${ }^{3} \mathrm{H}$ are buried at that facility. Some of these samplers collect tritium concentrations that are higher than background levels. In 1996, the monitors at the tunnel pond area, near the SEDAN crater and at the EPA Farm, measured tritium at slightly higher than background concentrations. The monitoring results from these sampling stations are provided in Table D.1. The other CY96 monitoring data indicate that gross beta and ${ }^{239+240} \mathrm{Pu}$ concentrations in air at RWMS-5 are not statistically different from NTS sitewide levels.

\section{SOURCE TERM}

It is estimated that $0.35 \mathrm{Ci}(13 \mathrm{Gbq})$ of ${ }^{3} \mathrm{H}$ is emitted annually from the RWMS. This source term is calculated to give an EDE of $4.7 \mathrm{nrem}(0.047 \mathrm{nSv})$ to an individual residing in Lathrop Wells, Nevada. This is the location of the MEI for a source in Area 5. The method used to calculate this quantity is described below.

Only environmental monitoring data were available and there was no information on the volume of air discharged from the RWMS. Considering that the RWMS only processes packaged waste, it is not likely that an air volume or discharge can be determined. However, a source term can be calculated using a method similar to that described for Yucca Flat in Appendix E.

The mean annual airborne HTO concentrations from the RWMS tritium samplers surrounding the site were used along with the DOE/EH-0071 dose conversion factors to calculate a dose at each sampler location. For example, an individual breathing $2.3 \times 10^{-12} \mu \mathrm{Ci} / \mathrm{mL}$ of HTO for one year receives $1.8 \mu \mathrm{rem}$ EDE when skin absorption is included. ${ }^{(4)}$ Doses are calculated similarly for the other sampler locations. The result of a CAP88-PC run, assuming a $1 \mathrm{Ci}$ release of ${ }^{3} \mathrm{H}$ at the center of the RWMS, is that an individual $381 \mathrm{~m}$ to the southeast (the location of that sampler) would receive an EDE of $14 \mu \mathrm{rem}$ per year. Therefore, $1.3 \mu \mathrm{rem}$ measured at that sampler divided by $14 \mu \mathrm{rem} / \mathrm{Ci}$ (from CAP88PC) equals an estimated annual release of $0.13 \mathrm{Ci}$. This calculation was performed for all sampler locations, as shown in Table D. 1 and a release of 0.35 $\mathrm{Ci}(13 \mathrm{GBq})$ was the maximum estimate as shown in the last column of Table D.1.

Lathrop Wells, Nevada, is located west-southwest of the RWMS at $44 \mathrm{~km}$. Use of CAP88-PC results in an EDE of $4.7 \times 10^{-6}$ mrem to an individual residing in Lathrop Wells if 0.35 curies of HTO were released from the RWMS-5.

The other samplers with elevated mean concentration of HTO in air are at the Area 10 SEDAN Crater and the E Tunnel Pond. The E Tunnel Pond emission is calculated in Appendix B. The emission from the SEDAN crater (calculated from air sampler data as above) is shown in the table, assuming it is the source. Note that the sampler installed at SEDAN detected an HTO

(4) The following equation was used to calculate an EDE at each sampler location:

$E D E=p C i / \mathrm{m}^{3} \times 8400 \mathrm{~m}^{3} / \mathrm{yr}$ (inhaled) $\times 1.5$ (skin abs.) $\times 6.2 \times 10^{-8} \mathrm{mrem} / \mathrm{pCi}$ where $\mathrm{pCi} / \mathrm{m}^{3}$ is the annual average HTO concentration. 
level higher than the Area 15 Farm sampler. It also appears unlikely that as much as $140 \mathrm{Ci}$ of HTO are being emitted from the SEDAN crater. However, there is no other likely source of the tritium in atmospheric moisture measured in that area. Therefore, the RWMS-5 and the SEDAN crater are considered to be sources for emission of HTO on the NTS.

Table D.1 Airborne Tritium Sampling Results During CY96

\begin{tabular}{|c|c|c|c|c|c|}
\hline \multirow{2}{*}{$\begin{array}{l}\text { Sampler } \\
\text { Number }\end{array}$} & \multirow{2}{*}{\multicolumn{2}{|c|}{$\begin{array}{l}\text { Direction }{ }^{(a)} \\
\text { from Center }\end{array}$}} & \multicolumn{2}{|c|}{ Mean } & \multirow{2}{*}{$\begin{array}{l}\text { Ratio to } 1 \mathrm{Ci} \\
\text { Emission }\end{array}$} \\
\hline & & & $\mu \mathrm{Ci} / \mathrm{mL}$ & $\underline{\mathrm{bq} / \mathrm{m}^{3}}$ & \\
\hline 05915 No. 1 & $S E$ & $381 \mathrm{~m}$ & $2.3 \times 10^{-12}$ & 0.08 & 0.13 \\
\hline 05911 No. 3 & $E$ & $305 m$ & $2.7 \times 10^{-12}$ & 0.10 & 0.08 \\
\hline 05700 No. 4 & NE & $418 \mathrm{~m}$ & $5.4 \times 10^{-12}$ & 0.20 & 0.35 \\
\hline 05707 No. 5 & $N$ & $305 m$ & $6.1 \times 10^{-12}$ & 0.23 & 0.18 \\
\hline 05708 No. 6 & NW & $418 \mathrm{~m}$ & $2.8 \times 10^{-12}$ & 0.10 & 0.16 \\
\hline 05709 No. 7 & W & $305 \mathrm{~m}$ & $3.0 \times 10^{-12}$ & 0.11 & 0.06 \\
\hline 05714 No. 8 & SW & $418 \mathrm{~m}$ & $2.9 \times 10^{-12}$ & 0.11 & 0.15 \\
\hline 05716 No. 9 & $\mathrm{~S}$ & $305 m$ & $3.8 \times 10^{-12}$ & 0.14 & 0.10 \\
\hline 15115 Farm & & & $4.7 \times 10^{-12}$ & 0.17 & \\
\hline SEDAN Crater & $N$ & $1290 \mathrm{~m}$ & $8.9 \times 10^{-12}$ & 0.33 & 140 \\
\hline Area 12 Camp & & & $0.9 \times 10^{-12}$ & 0.03 & \\
\hline E Tunnel Pond & & & $12.6 \times 10^{-12}$ & 0.47 & \\
\hline U-3ah/at North & & & $0.8 \times 10^{-12}$ & 0.03 & \\
\hline H\&S Building & & & $0.1 \times 10^{-12}$ & 0.004 & \\
\hline
\end{tabular}

(a) Sampler direction and distance from center of suspected source.

(b) This ratio = number curies emitted from RWMS that would give the sampler result. 


\section{APPENDIX E \\ RESUSPENDED PLUTONIUM FROM YUCCA FLAT \\ AND OTHER AREAS}

\section{BACKGROUND INFORMATION}

Area 3 on the NTS is a diffuse source of radionuclide effluents. Due to operational activities, such as vehicular traffic, equipment operation, etc., some soil becomes airborne. Results from the air samplers in the area indicate that ${ }^{239+240} \mathrm{Pu}$ is routinely detected, but only in concentrations slightly above the MDC. Few of the 30 air sampler locations on the NTS had concentrations exceeding the network average by four standard deviations (the criterion used for a high result).

Measurements of airborne ${ }^{239+240} \mathrm{Pu}$ in Area 3, during CY96, are provided in Table E.1. This table displays the number of samples analyzed, the mean value, and the standard deviation of the values. Because Area 3 is an area source, it is difficult to measure the volume of air discharged. Therefore, the source term must be estimated. In order to obtain a source term in $\mathrm{Ci} / \mathrm{yr}$ from the area, the measured ${ }^{239+240} \mathrm{Pu}$ concentration was used in conjunction with CAP88-PC in order to back calculate a source term. For convenience, the source was assumed to be an area in the center of a circle that touches the five sampling locations (worst-case assumption).

Table E.1 Airborne ${ }^{239+240} \mathrm{Pu}$ Detected by Area 3 Air Samplers

$\left(\mu \mathrm{Ci} / \mathrm{mL} \times 10^{-18}\right)$

$\begin{array}{ccc}\text { Location } & \begin{array}{c}\text { Number of } \\ \text { Samples }\end{array} \text { Mean } & \begin{array}{c}1 \text { Standard } \\ \text { Deviation }\end{array}\end{array}$

Area 03 Mud Plant

$3 \quad 130$

Area 03 U3ah/at (4 Samplers)

36

180

130

\section{SOURCE TERM}

It is estimated that $12 \mathrm{mCi}(0.42 \mathrm{Gbq})$ of ${ }^{239+240} \mathrm{Pu}$ may have been emitted from Area 3 . This source term is only probable, because it is a worst-case value that is based on calculations and an assumed location rather than on effluent monitoring. The method used to calculate this quantity is described below.

The CY96 mean concentration of ${ }^{239+240} \mathrm{Pu}$ at the Area 3 samplers was tabulated as above. Using the dose conversion factor of $330 \mathrm{rem} / \mu \mathrm{Ci}$ derived from the International Commission on Radiological Protection Annual Limits of Intake (using class $Y$ ) and $8,400 \mathrm{~m}^{3}$ annual average air intake per person, an EDE can be calculated for a person remaining all year at that sampler location.

A trial run of CAP88-PC using a $1 \mathrm{Ci}$ release from the center of the samplers gives an EDE at each of them. When the calculated EDE at each sampler, using that sampler's annual average concentration, is divided by the EDE/Ci from the CAP88-PC run, then an estimate of the curies released can be obtained.

The following shows a typical calculation, using the first datum in Table $E .1\left(\mu \mathrm{Ci} / \mathrm{mL} \times 10^{12}=\mathrm{pCi} / \mathrm{m}^{3}\right)$ :

$$
13 \times 10^{-5} \mathrm{pCi} / \mathrm{m}^{3} \times 8,400 \mathrm{~m}^{3} / \mathrm{yr} \times 0.33 \mathrm{mrem} / \mathrm{pCi}=0.36 \mathrm{mrem}
$$


A CAP88 run using $1 \mathrm{Ci}$ and $670 \mathrm{~m}$ distance indicates an EDE of $220 \mathrm{mrem}$ at the location of the sampler. The ratio of $0.36 \mathrm{mrem}$ (measured) to 220 gives $1.6 \times 10^{-3} \mathrm{Ci}$ as an emission. Using the data in the above table indicates the maximum emission (based on the U-3ah/at samplers) would be $2.4 \mathrm{mCi}(89 \mathrm{MBq})$. Wind transport has only extended the boundaries of the plutonium contaminated areas a few meters since the 1960 s so it is not very mobile, and only a fraction of the amount resuspended would be in particle sizes small enough to be carried very far by the wind. This suggests that the calculated emission may be greater than the actual amount.

However, a more consenvative calculation is to use the resuspension equation as is done below for the plutonium deposit in Area 9. In that case the emission would be 12 mCi per year. Using CAP88-PC, this would yield an EDE of 0.005 mrem to a person in Springdale, the offsite MEI.

\section{ERROR TERM}

The errors in the measurements are listed in Table E.1 as a standard deviation, so the EDE is most likely between 0 and $2 \times 10^{-2}$ mrem $\left(0\right.$ and $\left.10^{-2} \mathrm{mSv}\right)$. However, the errors that occur in estimating a source term, as described above, are very difficult to assess.

\section{CALCULATION OF PLUTONIUM RESUSPENSION FROM AREA 9}

There is an air sampler in Area 9 at one end of a ground deposit of plutonium that usually collects air samples having a higher concentration than the NTS average, but it would require too many assumptions to use the above method. McArthur, in DOE/NV/10845-02, estimates a ${ }^{238+240} \mathrm{Pu}$ deposit of $75.6 \mathrm{Ci}$ on $7.5 \mathrm{mi}^{2}$ of Area 9 . If the rate of resuspension of that material can be calculated, then a source term would be available.

In the book "Radiological Assessment" by J. E. Till and H. R. Meyer, pages 5-30, an equation for calculating a suspension rate (fraction resuspended per second) is given as follows:

$$
S=K \times V_{g}
$$

where: $\quad S=$ suspension rate $\left(\sec ^{-1}\right)$ - fraction of the deposit resuspended/sec

$K=$ resuspension factor $\left(\mathrm{m}^{-1}\right)$

$\mathrm{V}_{\mathrm{g}}=$ deposition velocity $(\mathrm{m} / \mathrm{s})$

On page 75 of report DOE/NV-357, values of $\mathrm{K}$ are given for the NTS. An average of the values given is $2 \times 10^{-10}$ per meter. Deposition velocities in the range of 0.01 to 0.05 meter per second will be used as conservative estimates. If these values are put into the above equation, the rate of suspension is between $2 \times 10^{-12}$ and $1 \times 10^{-11}$ per second, and the source term becomes:

$$
75.6 \mathrm{Ci} \times 10^{12} \mathrm{pCi} / \mathrm{Ci} \times 1 \times 10^{-11} / \mathrm{s}=756 \mathrm{pCi} / \mathrm{s}
$$

Since 1 year $=3600 \mathrm{~s} / \mathrm{hr} \times 24 \mathrm{hr} /$ day $\times 365$ days $/ \mathrm{yr}=3.15 \times 10^{7} \mathrm{~s} / \mathrm{yr}$, the annual source term becomes:

$756 \mathrm{pCi} / \mathrm{s} \times 3.15 \times 10^{7} \mathrm{~s} / \mathrm{yr}=2.38 \times 10^{10} \mathrm{pCi} / \mathrm{yr}(24 \mathrm{mCi} / \mathrm{yr})$

or, with the $2 \times 10^{-12}$ value for $S$ :

$$
4.76 \times 10^{9} \mathrm{pCi} / \mathrm{yr}(4.8 \mathrm{mCi} / \mathrm{yr}) .
$$

Therefore, using the above suspension rate, the emission is between 4.7 and $24 \mathrm{mCi} / \mathrm{yr}$. Using the larger value, this emission was input to the CAP88 program using the Area $9-300$ bunker as the midpoint of the source. 
A similar calculation was performed for all other plutonium contaminated areas on the NTS and the Nellis Air Force Range Complex. That is, the areal estimate of Pu deposition from McArthur is used with the resuspension equation to obtain a source term. The results are shown in Table E.2.

Using the equation in EPA's Methods for Estimating Diffuse Emissions (July 1994 draft), another calculation can be done.

\section{WIND EROSION CALCULATION FOR AREA 9 - COMPARISON WITH NTS NESHAP REPORT}

The equation used is on page 18 of the EPA report:

$$
E^{\prime}=K \cdot a \cdot I \cdot K \cdot C \cdot L^{\prime} \cdot V^{\prime} \cdot A \cdot c
$$

where: $\quad E^{\prime}=$ soil particles lost (tons/yr)

$k=$ particle size factor

$a=$ total suspended fraction lost to wind erosion

$I=$ soil erodibility (tons/acre-yr)

$K=$ surface roughness factor

$C=$ climatic factor $\left(C=0.345\left(\mathrm{mph}^{3} / \mathrm{PE}^{2}\right)\right.$ where $\left.\mathrm{PE}=0.83\right)$

$L^{\prime}=$ unsheltered field width factor

$V^{\prime}=$ vegetative cover factor

$A=$ site area $\left(\mathrm{m}^{2}\right)-$ use high density of $75.6 \mathrm{Ci}$ on $7.5 \mathrm{mi}^{2}$

$c=$ conversion factor tons/acre to $\mathrm{kg} / \mathrm{m}=0.224$

Inputs: Yucca Flat is typical high plain desert with sparse vegetation. Average wind speed is $6.0 \mathrm{knots}=6 \times 0.514 \mathrm{~m} / \mathrm{s}=3.08 \mathrm{~m} / \mathrm{s}=11.1 \mathrm{~km} / \mathrm{hr}(6.9 \mathrm{mph})$;

$k=0.5$ (fraction of resuspended soil that is $P M_{10}$ )

$a=0.025$ portion of total erosion that is suspended particulates

$I=28$ (silty clay loam from Table 7-1, desert pavement decreases erodibility)

$K=1$ (surface roughness - desert is smooth)

$C=164$ (climatic factor calculated from $C=0.345(\mathrm{mph})^{3} /(0.83)^{2}$

$L^{\prime}=0.3$ as read from Figure $7-5$ (IK $=28 \times 0.6=17, L=500$ from Table 7-3)

$V^{\prime}=0.95$ (read from Figure 7-6 using $V=100$ from Table 7-3 and $I K C L^{\prime}=790$ )

$A=7.5 \mathrm{mi}^{2}=1.9 \times 10^{7} \mathrm{~m}^{2}$ from McArthur' s report

so:

$$
E^{\prime}=0.5 \times 0.025 \times 28 \times 1 \times 164 \times 0.3 \times 0.95 \times 0.224=3.7 \mathrm{~kg} / \mathrm{m}^{2}-\mathrm{yr}
$$

Area 9 (From McArthur): $75.6 \mathrm{Ci}$ on $7.5 \mathrm{mi}^{2}\left(7.5 \times 2.59 \times 10^{6} \mathrm{~m}^{2} / \mathrm{mi}^{2}\right)$ or $1.9 \times 10^{7} \mathrm{~m}^{2}$ Total Emission $=3.7 \mathrm{~kg} / \mathrm{m}^{2}-\mathrm{yr} \times 1.9 \times 10^{7} \mathrm{~m}^{2}=7.0 \times 10^{7} \mathrm{~kg} / \mathrm{yr}$

$\mathrm{Pu}$ concentration in dust (assuming all $\mathrm{Pu}$ is in top $5 \mathrm{~cm}$ ):

$1.9 \times 10^{7} \mathrm{~m}^{2} \times 10^{4} \mathrm{~cm}^{2} / \mathrm{m}^{2} \times 5 \mathrm{~cm}$ deep $\times 1.5 \mathrm{~g} / \mathrm{cm}^{3}=1.4 \times 10^{12} \mathrm{~g}$ becomes:

$75.6 \mathrm{Ci} \times 10^{12} \mathrm{pCi} / \mathrm{Ci} \div 1.4 \times 10^{12} \mathrm{~g}=53 \mathrm{pCi} / \mathrm{g}$ or $53 \mathrm{nCi} / \mathrm{kg}$ and the source-term

$$
53 \times 10^{-9} \mathrm{Ci} / \mathrm{kg} \times 7.0 \times 10^{7} \mathrm{~kg} / \mathrm{yr}=3.7 \mathrm{Ci} / \mathrm{yr}
$$

If the total deposit in Area 9 is $75.6 \mathrm{Ci}$ and the $\mathrm{E}^{\prime}$ calculation performed is correct, then $75.6 \mathrm{Ci} \div 3.7 \mathrm{Ci} / \mathrm{yr}=20.4$ suggests that the deposit would be depleted in about 20 years.

On the other hand, the resuspension equation calculation $(0.0238 \mathrm{Ci} / \mathrm{yr})$ would require about 3200 years to deplete the deposit. 
Table E.2 Offsite EDE Calculated from Resuspension of Pu from NTS Areas - 1996 ( $\mu$ rem)

\begin{tabular}{|c|c|c|c|c|c|c|c|c|c|c|}
\hline Location & Population & Area 3 & Area 9 & Area 10 & Area 11 & Area 13 & Area 18 & Area 19 & $\begin{array}{l}\text { Clean } \\
\text { Slate } \\
\end{array}$ & $\begin{array}{l}\text { Sum } \\
\text { mrem }\end{array}$ \\
\hline & Deposit ar & $37 \mathrm{Ci}$ & $75.6 \mathrm{Ci}$ & $220 \mathrm{Ci}$ & $36 \mathrm{Ci}$ & $46 \mathrm{Ci}$ & $100 \mathrm{Ci}$ & $181 \mathrm{Ci}$ & $58 \mathrm{Ci}$ & \\
\hline Alamo & 1,000 & & & 5.8 & & 1.6 & & & & 0.0074 \\
\hline Amargosa Valley & 30 & 6.8 & 12 & 30 & 6.5 & & 15 & 11 & & 0.0813 \\
\hline Amargosa Center & 1,200 & 3.7 & 9.5 & 24 & 4.0 & & 9 & 9.9 & & 0.055 \\
\hline Ash Meadows & 10 & 4.0 & & & 4.1 & & 6 & & & 0.028 \\
\hline Ash Springs & 70 & & & & & 1.9 & & & & 0.0019 \\
\hline Beatty & 1,500 & 4.9 & 9.5 & 26 & 3.8 & & 3.3 & 29 & & 0.075 \\
\hline Clark's Station & 2 & & & & & & & & 12 & 0.0125 \\
\hline Crystal & 45 & 3.9 & 6.5 & 17 & 7 & & 20 & & & 0.054 \\
\hline Goldfield & 600 & & & & & & & & 4.4 & 0.0044 \\
\hline Goldpoint & 15 & & & & & & & & & 0 \\
\hline Hiko & 103 & & & & & 1.8 & & & & 0.0018 \\
\hline Indian Springs & 1,200 & 1.5 & 4.4 & 11 & 3.8 & & & & & 0.0207 \\
\hline Lida & $15^{-}$ & & & & & & & & & 0 \\
\hline Lida Junction & 8 & & & & & & & 5.2 & 9 & 0.0142 \\
\hline Medlin's Ranch & 2 & 2.4 & 5.5 & 13 & 2.3 & 6 & 1.9 & 3.6 & & 0.0345 \\
\hline Mercury & 550 & 9.7 & 12 & 29 & 10 & 3.8 & 29 & 5.7 & & 0.0985 \\
\hline Pahrump & 20,000 & & & & & & & & & \\
\hline Penoyer Farm & 16 & 2 & 4.4 & 16 & 1.5 & 5.5 & 2 & 7.3 & 0.9 & 0.0395 \\
\hline
\end{tabular}


Table E.2 (Offsite EDE Calculated from Resuspension of Pu from NTS Areas - 1996 [urem], cont.)

\begin{tabular}{|c|c|c|c|c|c|c|c|c|c|}
\hline Population & Area 3 & Area 9 & Area 10 & Area 11 & Area 13 & Area 18 & Area 19 & $\begin{array}{l}\text { Clean } \\
\text { Slate } \\
\end{array}$ & $\begin{array}{c}\text { Sum } \\
\text { mrem }\end{array}$ \\
\hline Deposit $\propto$ & $37 \mathrm{Ci}$ & $75.6 \mathrm{Cl}$ & $220 \mathrm{Ci}$ & $36 \mathrm{Ci}$ & $46 \mathrm{Ci}$ & $100 \mathrm{Cl}$ & $181 \mathrm{Ci}$ & $58 \mathrm{Ci}$ & \\
\hline Rachel & 1.9 & 4.3 & 15 & 1.6 & 6 & 2 & 4 & & 0.0345 \\
\hline Sarcobatus Flat & 2.3 & & & & & 7.5 & $15^{-}$ & 4.6 & 0.0285 \\
\hline Silver Peak & & & & & & & & & $\underline{0}$ \\
\hline So. Nev. Corr. Inst. 2000 & 1.1 & & & 1.4 & & & & & 0.0025 \\
\hline Springdale & 5 & 9.5 & 27 & 3.8 & & 3.6 & 37 & 3 & 0.0889 \\
\hline Stateline & 3.2 & & . & 4.1 & & 6.5 & & & 0.0138 \\
\hline Stone Cabin & & & & & & & & 9.5 & 0.0095 \\
\hline Tonopah & & 3.8 & & & & & & 4.2 & 0.008 \\
\hline Twin Springs & & & & & & & & 2.4 & 0.0024 \\
\hline US Ecology & 4.9 & 8.5 & 21 & 4.2 & & 4.6 & 15 & & 0.0582 \\
\hline Calculated Emission - mCi & 12 & 24 & 69 & 11 & 14 & 32 & 57 & 18 & 237 \\
\hline
\end{tabular}




\section{APPENDIX F \\ IDENTIFICATION AND JUSTIFICATION FOR THE DEVELOPMENT OF METEOROLOGICAL DATA USED AS INPUT TO CAP88-PC}

\section{INTRODUCTION}

The NTS is located in southern Nevada, approximately $90 \mathrm{~km}$ (56 mi) northwest of Las Vegas, and encompasses an approximate rectangular area of $1,350 \mathrm{sq} \mathrm{mi}$ (see Figure G.1).

Topography is complex with generally north-south oriented ridges and valleys typical of Nevada. Terrain elevations range from near $2,700 \mathrm{ft}$ in the extreme southwest corner of the NTS (Station No. 25) to near $7,700 \mathrm{ft}$ on Rainier Mesa in the northern part of the NTS (Station No. 12).

In general, terrain slopes gently into broad valleys. In the few areas where steep canyons or cliffs exist, adequate wind and temperature data have been collected and analyzed to provide thorough documentation of the existence of typical up-slope and down-slope wind regimes as a function of time of day.

Meteorological support, observations, and climatological services for the NTS are provided to the DOE/NV by the ARL/SORD. The ARL/SORD is a National Oceanic and Atmospheric Administration (NOAA) office and supports DOE/NV programs under the authority of an Interagency Agreement between NOAA and DOE/NV.

An arid climate exists over the NTS. Annual precipitation ranges from $4.5 \mathrm{in} / \mathrm{yr}$ at Station No. 25 to $6.9 \mathrm{in} / \mathrm{yr}$ in Yucca Flat, to $7.6 \mathrm{in} / \mathrm{yr}$ at Desert Rock, and to $9.5 \mathrm{in} / \mathrm{yr}$ on Rainier Mesa .

\section{METEOROLOGICAL OBSERVATIONS}

The ARLSORD manages, operates, and maintains a meteorological monitoring program that is designed and used to support the DOE/NV authorized activities on the NTS. This vital program consists of many meteorological monitoring systems that have been brought together under the acronym MIDNET, or Meteorological Data Network. This network has been operated on the NTS for over 25 years, has undergone several modernizations and upgrades, and serves as a solid basis for deriving climatological information.

MIDNET consists of communications systems, local area networks, upper air sounding stations, and surface-based instrumentation used to measure wind direction and speed, temperature, relative humidity, and precipitation. Routine and special surface observations are collected by trained ARL/SORD personnel $24 \mathrm{hr} / \mathrm{da}, 365 \mathrm{da} / \mathrm{yr}$ at the Desert Rock Meteorological Observatory (DRA, elevation 3,304 ft) located three miles southwest of Mercury, Nevada (Station No. 23). Upper-air observations (radiosondes) are taken twice daily from DRA. DRA has been in operation since June 1978. The DRA was built to replace a similar observatory that was located in Yucca Flat Meteorological Observatory (UCC, elevation 3,924 ft, Station No. 6) from January 1962 through April 1978. Consequently, surface and upper-air observations are also available from UCC for 1962-1978.

A key component of the MIDNET system is the Meteorological Data Acquisition System (MEDA). MEDA consists of an enclosed trailer, a portable 10-m tower, an electric generator (where needed), a microprocessor, and a microwave radio transmitter. Wind speed and direction sensors are located on booms oriented into the prevailing wind direction and at a minimum distance of two tower widths from the tower. Wind sensors are located $10 \mathrm{~m}$ above the ground. 
Wind and temperature data have been collected on the NTS for more than 25 years. These and other meteorological data have been compiled into a comprehensive climatological database for the NTS. The MEDA data are specially useful in assessing boundary layer flow regimes on the NTS. MEDA station distribution and density (see Figure G.1) are sufficient to document individual basin flow regimes and potential interbasin air exchanges.

Ambient temperature and relative humidity sensors are located at the 3-m level. A total of 40-50 MEDA stations are located on or around the NTS (see Figure G.1) to ensure that meteorological conditions are thoroughly documented for the complex terrain environment found on the NTS.

Wind direction is measured to two degrees of azimuth, and wind speed is accurate to $0.15 \mathrm{mph}$. Wind data are collected as 4-min averages and are transmitted via microwave to a central processor every $15 \mathrm{~min}$. These data are checked operationally by the duty forecaster, and quality control is assured by the ARLSORD climatologist. Plotted wind products are generated every $15 \mathrm{~min}$ for operational use. The data are stored and archived for climatological purposes.

MEDA temperature is accurate to 0.035 percent between $0^{\circ} \mathrm{C}$ and $40^{\circ} \mathrm{C}$. Temperature measurements are instantaneous and are taken every $15 \mathrm{~min}$ at all MEDA stations. These data are also transmitted via microwave to a computer for processing, display, and archiving.

To utilize the most representative meteorological data available for NTS sources, cloud observations from DRA were melded with the concomitant MEDA winds from Mercury and Pahute Mesa. Similarly, the cloud observations from UCC were melded with MEDA wind data from Yucca and Frenchman Flats. The straight-line distance from DRA to Mercury is $3 \mathrm{mi}$; from UCC to Frenchman Flat, $12 \mathrm{mi}$; and from DRA to Pahute Mesa, $40 \mathrm{mi}$.

Cloud cover observations needed as input to the STAR program are available from DRA (1978-present) and from UCC (1962-1978). Based on the available data, the cloud cover climatology from DRA and UCC are quite compatible. For example, UCC experiences 192 clear days annually while DRA has 191 days. In addition, the average annual sky cover, in tenths, from sunrise to sunset for both stations is 3.9 tenths daily. The total number of cloudy days for UCC is 81 days and 88 days for DRA, annually. Therefore, the cloud cover observations from DRA and UCC can be considered as representative for most of the NTS.

In a study of precipitation on the NTS, Quiring $(1983)^{(5)}$ found that the northwest part of the NTS, including Pahute Mesa, is clearly an area of diminished precipitation for the given elevation $(6,500 \mathrm{ft})$. Furthermore, the total annual precipitation for Pahute Mesa (9.5 in) is more compatible with that from DRA (7.6 in) than from UCC (6.9 in). Consequently, assuming that cloud cover is directly related to precipitation, it logically follows that the cloud cover for Pahute Mesa is better represented climatologically by the cloud observations from DRA.

(5) Quiring, R.F., "Precipitation Climatology for the NTS," NOAA Weather Service Nuclear Service Office (WSNSO), Las Vegas, NV, WSNSO 351-88, 34 pp., 1983. 


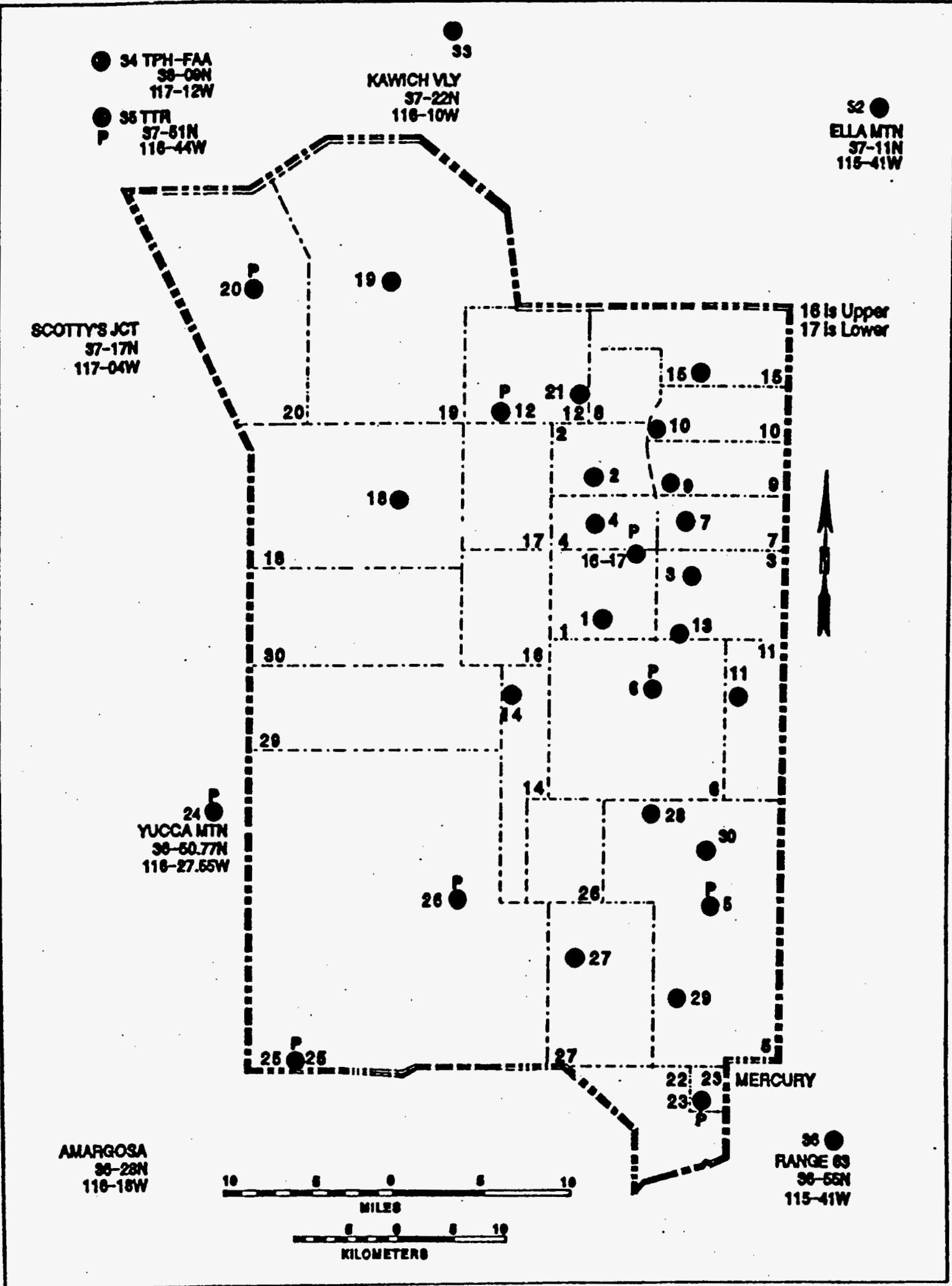

Figure F.1 Location of MEDA Stations on the NTS 


\section{CONCLUSIONS}

Based on the above considerations and on the limitations of CAP88, the cloud cover data from DRA were considered to be representative of Pahute Mesa. Therefore, atmospheric soundings and cloud cover observations from DRA were melded with MEDA surface wind data from Pahute Mesa for input to the STAR program to provide the very best data for calculating transport and dispersion processes.

For sources in Yucca Flat and Frenchman Flat, the cloud cover data from UCC were considered to be the most representative. Yucca Flat and Frenchman Flat are adjoining valleys of similar soil and vegetation types and similar meteorological and climatological conditions.

For sources at Mercury, the cloud observations from DRA are representative. DRA is only 3 mi from Mercury.

The STAR file is a matrix that includes 6 Pasquill stability categories ( $A$ through F), 6 wind speed categories, and 16 wind sectors from wind roses calculated for each specified MEDA station on the NTS. 


\section{APPENDIX G \\ SUPPLEMENTAL INFORMATION}

\section{COMPARISON WITH PREVIOUS YEARS' DATA}

Maximum Potential Individual EDE:

$$
\begin{aligned}
& 1996-1.1 \times 10^{-1} \mathrm{mrem}(1.1 \mu \mathrm{Sv}) \\
& 1995-1.8 \times 10^{-1} \mathrm{mrem}(1.8 \mu \mathrm{Sv}) \\
& 1994-1.5 \times 10^{-1} \mathrm{mrem}(1.5 \mu \mathrm{Sv}) \\
& 1993-3.8 \times 10^{-3} \mathrm{mrem}(38 \mathrm{nSv}) \\
& 1992-1.2 \times 10^{-2} \mathrm{mrem}(120 \mathrm{nSv}) \\
& 1991-8.6 \times 10^{-3} \mathrm{mrem}(86 \mathrm{nSv})
\end{aligned}
$$

In 1990, containment pond evaporation of HTO was added to the NTS source term. The HTO effluents from the tunnels were three times higher in 1991. In 1992, there was a 15 percent increase in HTO effluents, and the STAR for the tunnel area was developed that slightly changed the offsite distribution of the effluent. In 1993, tunnel effluents began decreasing because of sealing the tunnel drainage systems. In 1994, resuspension of plutonium from surface deposits was calculated. Area 20 emissions increased this year (krypton seepage and HTO from characterization wells). The 1996 decrease is due to decreased emissions and cleanup of areas.

\section{COLLECTIVE EFFECTIVE DOSE EQUIVALENT}

The maximum potential collective effective dose equivalent to the 32,210 people who live within $80 \mathrm{~km}$ of the NTS emission sources was 0.34 person-mrem in 1996, about 99 percent was due to the calculated resuspended plutonium exposure. Tritium exposure was higher than last year because of the effluent from characterization well ponds. The collective EDE data are based on distance and direction from each of the sources of emission on the NTS and nearby areas. These data are displayed in the last column of Table 5.0. The collective EDE is the sum of the EDE to the community from each emission source multiplied by the population of the community.

Maximum Potential Collective EDE (person-mrem) by NTS Source:

\begin{tabular}{lc} 
Areas 3,9 & 63 \\
Area 5 & 0.11 \\
Area 12 & 0.14 \\
Other Areas & 275 \\
Area 20 & 0.98 \\
& 339 person-mrem \\
\cline { 2 - 2 } & $(0.34$ person-rem $)$
\end{tabular}

The higher potential population doses from plutonium areas are due to the conservative assumptions about resuspension of plutonium from deposited material in those areas. The extent of overestimation was assessed in the 1994 report as follows: calculate the concentration of ${ }^{239} \mathrm{Pu}$ necessary to cause the CAP88-PC estimate of EDE. The CAP88-PC estimate was 0.15 mrem at Lathrop Wells due to resuspension. With a dose conversion factor of $308 \mathrm{rem} / \mu \mathrm{Ci}$ (from Federal Guidance Report 11) and an inhalation intake of $8,400 \mathrm{~m}^{3}$ per year, obtain the concentration by dividing the $0.15 \mathrm{mrem}$ by $0.31 \mathrm{mrem} / \mathrm{pCi}$ and by $8,400 \mathrm{~m}^{3}$ to obtain a concentration of $58 \times 10^{-5} \mathrm{pCi} / \mathrm{m}^{3}$. This is higher than the $3 \times 10^{-6} \mathrm{pCi} / \mathrm{m}^{3}$ measured at Lathrop Wells by the EPA and indicates the conservatism in the calculation. 


\section{COMPLIANCE WITH NESHAP}

DOE/NV was in compliance with Title 40 C.F.R. 61, Subpart H, during CY96. Periodic confirmatory measurements and analyses of the NTS environs are provided in Appendices A through $F$. These measurements and analyses are the methods of determining NTS effluents presented in the April 24, 1991, meeting between Region 9 and DOE/NV and are documented in the 1990 through 1995 DOE/NV annual NESHAP reports.

\section{COMPLIANCE WITH SUBPARTS Q AND T, Title 40 C.F.R. 61}

The NTS is regulated by Subpart $H$ not Subparts $Q$ and T. Measurements of radon-220 and -222 have not been made. Short-lived radon progeny may be detectable on particulate filters from air samplers deployed around the Radioactive Waste Management Facility.

\section{RADON EMISSIONS FROM U-238 AND TH-232 SOURCES}

Material from Mound Applied Technologies is stored in cargo containers at the RWMS - 5. Thermoluminescent dosimeters placed around the containers have not detected an increase in gamma exposure that would occur as radon progeny accumulate in the cargo containers.

\section{NON-DISPOSAL/NON-STORAGE SOURCES OF RADON EMISSION}

None of these sources exist on the NTS.

\section{NESHAP QUALITY ASSURANCE PROGRAM}

Provisions in Method 114 described in Appendix B of Title 40 C.F.R. 61 are related to continuous monitoring of major sources. The NTS has only minor sources. 


\section{APPENDIX H \\ DISTRIBUTION LIST}

\section{DISTRIBUTION}

Director, Air \& Toxic Division, Region 9, U.S. Environmental Protection Agency, 75 Hawthorne Street, San Francisco, CA 94103

Paul Liebendorfer, Nevada Division of Environmental Protection, 123 W. Nye Lane, Carson City, NV 89710

Jerry Sirene, Nevada Division of Environmental Protection, 1515 E. Tropicana Avenue, Suite 395, Las Vegas, NV 89119

Radiological Health Section, Bureau of Health Protection Services, 505 E. King Street, Room 203, Carson City, NV 89710

A. Tinney, Bureau of Health Protection Services, 620 Belrose Street, Las Vegas, NV 89158-5242

Director, Office of RD\&T Facilities (DP-I 3 GTN), U.S. Department of Energy, 19901 Germantown Road, Germantown, MD 20545

Director, Office of Field Management (FM-I FORS), U.S. Department of Energy, 1000 Independence Avenue SW, Washington, DC 20585

R. W. Henderson, Los Alamos National Laboratory, Mercury, NV 89023 $\mathrm{M} / \mathrm{S} 967$

D. J. Thompson, Sandia National Laboratories, Post Office Box 5800, Albuquerque, NM 87185-5800

R. F. Pelletier (EH-23 FORS), U.S. Department of Energy, 1000 Independence Avenue SW, Washington, DC 20585 (2)

P. Weeden, Radiation Sciences Laboratory, U.S. Environmental Protection Agency, Post Office Box 93478, Las Vegas, NV 89193-3478, M/S 513

R. V. Dalson, Lawrence Livermore National Laboratory, Post Office Box 45, Mercury, NV 89023, M/S 777

J. R. Kannard, Environmental Management Division, Bechtel Nevada, Post Office Box 98521 , Las Vegas, NV 89193-8521, M/S NLV022

D. A. Bedsun, Defense Special Weapons Agency, Post Office Box 98539, Las Vegas, NV 89193-8518, M/S 573

M. L. Brown, IT Corporation, 4330 S. Valley View, Suite 114, Las Vegas, NV 89103 


\section{Distribution List, cont.}

K. Izell, Assistant Manager for Technical Services, Nevada Operations Office, U.S. Department of Energy, Post Office Box 98518, Las Vegas, NV 89193-8518, M/S 505

G. W. Johnson, Manager, Nevada Operations Office, U.S. Department of Energy Post Office Box 98518, Las Vegas, NV 89193-8518, M/S 505

L. J. Dever, Assistant Manager for Environmental Management, Nevada Operations Office, U. S. Department of Energy, P.O. Box 98518, Las Vegas, NV 89193, M/S 505

Waste Management Division, Nevada Operations Office U.S. Department of Energy, Post Office Box 98518, Las Vegas, NV 89193-8518, M/S 505 (3)

Environmental Protection Division, Nevada Operations Office U.S. Department of Energy, Post Office Box 98518, Las Vegas, NV 89193-8518, M/S 505 (3)

D. W. Duncan, Nevada Operations Office, U.S. Department of Energy, P. O. Box 98518, Las Vegas, NV 89193-8518, M/S 505

Technical Information Resource Center, Nevada Operations Office, U.S. Department of Energy, P. 0. Box 98518, Las Vegas, NV 89193-8518, M/S 505

Environmental Restoration Division, Nevada Operations Office, U.S. Department of Energy, P. 0. Box 98518 , Las Vegas, NV 89193-8518, M/S 505

S. Marshall, Bureau of Health Protection Services, 505 E. King Street, Carson City, NV 89710

L. Franks, Bureau of Health Protection Services, 620 Belrose Street, Las Vegas, NV 89158-5242

Office of Scientific and Technical Information, Technical Center, U.S. Department of Energy, P. O. Box 62, Oak Ridge, TN 37831 (2)

Martha E. DeMarre, Health Protection Department, Bechtel Nevada, P. O. Box 98521, Las Vegas, NV 89193-8521, M/S NLV040 


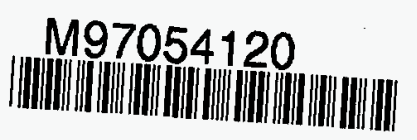

Report Number (14) DOE/NV/117/8_- 116

Publ. Date (11) $\frac{199706}{D O E / E A, X F}$
Sponsor Code (18)
UC Category (19) 